\title{
Oceanic redox conditions in the Late Mesoproterozoic recorded in the upper Vazante Group carbonates of São Francisco Basin, Brazil: Evidence from stable isotopes and REEs
}

\author{
Karem Azmy ${ }^{\mathrm{a}, *}$, Paul Sylvester ${ }^{\mathrm{a}}$, Tolentino F. de Oliveira ${ }^{\mathrm{b}}$ \\ a Department of Earth Sciences, Memorial University of Newfoundland, St. John's, NL, A1B 3X5 Canada \\ ${ }^{\mathrm{b}}$ Votorantim Metais, P.O. Box 03, 38780-000 Vazante MG, Brazil
}

\section{A R T I C L E I N F O}

\section{Article history:}

Received 3 January 2008

Received in revised form 10 October 2008

Accepted 14 October 2008

\section{Keywords:}

Vazante carbonates

Brazil

REE

$\mathrm{Th} / \mathrm{U}$

Redox conditions

\begin{abstract}
A B S T R A C T
The Vazante Group consists of a late Mesoproterozoic ( $1.0-1.1 \mathrm{Ga})$ carbonate-dominated marine platform sequence in east-central Brazil. The upper part of the sequence consists of a glaciomarine diamictite unit overlain by a cap carbonate. The $\delta^{13} \mathrm{C}$ profile of the upper Vazante shows significant negative plunges, one preglacial (drop of $\sim 5.5 \%$ VPDB) and two postglacial (drops of $\sim 9$ and $5 \%$.VPDB, respectively). The C-isotope plunge in the preglacial carbonates is correlated with low Th/U ratios (0.1-1.4) and a negative $\mathrm{Ce} / \mathrm{Ce}^{*}$ shift $(\sim 0.4)$, suggesting deposition under relative reducing conditions. In contrast, the C-isotope plunges in the postglacial carbonates are associated with high $\mathrm{Th} / \mathrm{U}$ ratios $(>2)$ and positive $\mathrm{Ce} / \mathrm{Ce}^{*}$ shifts (up to $\sim 1.5$ ), thus reflecting oxidizing conditions. Variations in the redox conditions of the late Mesoproterozoic ocean, reflected by changes in the $\mathrm{Th} / \mathrm{U}$ and $\mathrm{Ce} / \mathrm{Ce}^{*}$ ratios, are likely attributable to a combination of both global and local climatic and oceanographic changes, similar to what has been inferred for the Neoproterozoic oceans.
\end{abstract}

(c) 2008 Elsevier B.V. All rights reserved.

\section{Introduction}

Preserved marine carbonates are known to retain their primary chemical, elemental and isotopic, signatures that reflect the effect of prevailing oceanographic conditions and patterns (e.g., Wignall and Twitchett, 1996; Shields et al., 1997; Azmy et al., 1998; Veizer et al., 1999; Arnaboldi and Meyers, 2007; Wignall et al., 2007). Anoxic conditions have a dramatic impact on the organic productivity in oceans and, in most cases, may result in global mass extinction events (e.g., Wignall and Twitchett, 1996). Although anoxic events in the Phanerozoic oceans developed mainly in stratified oceans, the Neoproterozoic anoxia is believed to have been caused by extensive global glaciation that reached as far as the equatorial latitudes (Snowball Earth hypothesis) and the ice cover separated the ocean from atmosphere, thus resulting in severe drop in oxygen levels in sea surface waters (Hoffman et al., 1998; Hoffman and Schrag, 2002). These events were usually associated with the deposition of glaciogenic marine diamictites with dropstones and likely resulted in significant reduction in organic primary productivity and high rate of burial of organic carbon (cf. Halverson et al., 2005 and more references therein). The termination of glaciation left behind ${ }^{12} \mathrm{C}$ -

\footnotetext{
* Corresponding author. Tel.: +1 709737 6731; fax: +1 7097372589.

E-mail address: kazmy@mun.ca (K. Azmy).
}

depleted surface waters to recover productivity, which is reflected by the negative $\delta^{13} \mathrm{C}$ shifts exhibited in the cap carbonates immediately above the glaciogenic diamictites (e.g., Halverson et al., 2005, 2007). On the other hand, the redox conditions influence the oxidation state and solubility of some rare earth elements (REEs) in ocean water such as $\mathrm{Ce}$, and $\mathrm{U}$, relative to other elements that stay unaffected such as Th (e.g., Wignall and Twitchett, 1996; Shields et al., 1997).

Redox variations in the oceans prior to the Neoproterozoic have been the subject of some recent investigations (e.g., Kah et al., 1999; Schen et al., 2002, 2003; Arnold et al., 2004; Brocks et al., 2005) but remain poorly known and are worthy of further study. Thus, it is of some interest that remarkable negative $\delta^{13} \mathrm{C}$ shifts have been documented in cap carbonates of the upper Vazante Group diamictites of east-central Brazil (Azmy et al., 2001, 2006), which has recently been determined to have formed in the late Mesoproterozoic (Azmy et al., 2008). The current investigation presents evidence from Th, $U$ and other REE variations in the carbonates to evaluate the redox conditions associated with the glacial event that formed them.

\section{Geologic setting and age constraints}

The Vazante Group consists of a carbonate-dominated marine platform sequence (Dardenne, 2001) that extends along more than $300 \mathrm{~km} \mathrm{N-S}$ in the external zone of the Brasilia Fold Belt in São 


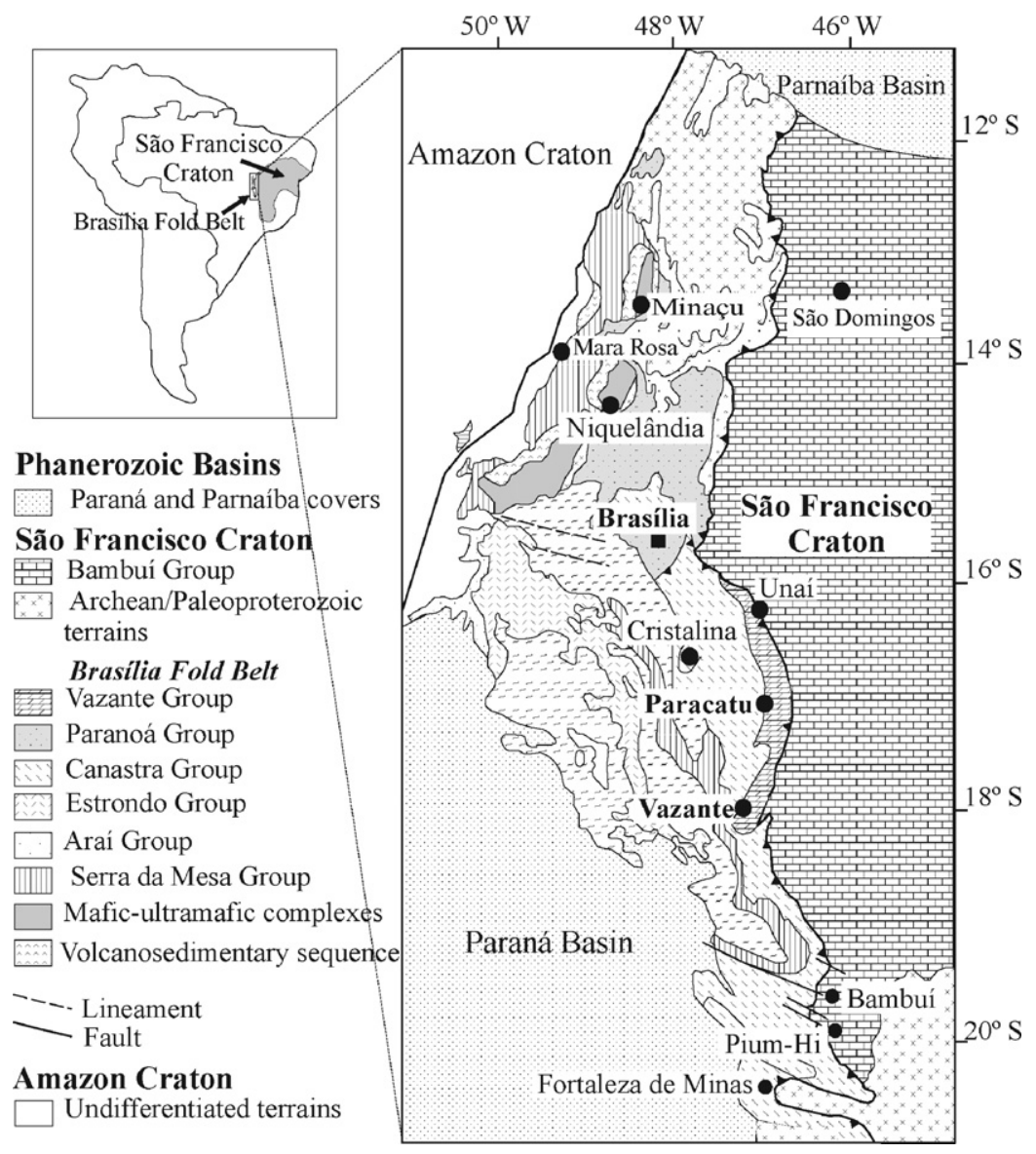

Fig. 1. Location map of São Francisco Basin in Brazil showing the geology of the Brasilia Fold Belt including the Vazante Group (modified from Valeriano et al., 2004).

Francisco Basin (Fig. 1). The stratigraphy of the marginal marine sediments of the Vazante Group (Fig. 2) has been studied in detail and refined by several authors (e.g., Dardenne, 1978; Dardenne and Walde, 1979; Madalosso, 1979; Karfunkel and Hoppe, 1988; Fairchild et al., 1996; Azmy et al., 2001, 2006; Dardenne, 2001; Misi, 2001; Misi et al., 2007). Sediments in the eastern part of the basin are generally preserved but they become highly deformed and metamorphosed (amphibolite to granulite facies) to the west near the Brazilia Fold Belt (Dardenne, 1978; Fuck et al., 1994). Earlier studies indicated that the Vazante Group sediments accumulated on a passive margin (e.g., Campos-Neto, 1984; Fuck et al., 1994), but recent investigations suggest that these sediments were deposited in a foreland basin during the initial phases of the Brasiliano orogeny (e.g., Dardenne, 2000) although the lack of evidence of volcanic activity (ash layers) in the sequence would favor the former model rather than the latter.

The Vazante Group is believed to rest on a glaciogenic unit (D), which constitutes the top of the Santo Antônio do Bonito Formation (Fig. 2) and includes another glacial horizon (D II) near the top of the succession (Olcott et al., 2005) at the base of the Lapa Formation (Azmy et al., 2006). Sedimentary iron-formation and iron-oxide cemented diamictites are also observed near the top of this second glaciogenic interval (Brody et al., 2004). A regional unconformity (Fig. 2) likely occurs at the base of the upper diamictite (D II) throughout the entire basin (Misi et al., 2007).

The Vazante Group stratigraphic framework is summarized in Fig. 2. Remarkable $\delta^{13} \mathrm{C}$, and REE, variations have been documented mainly in the upper part of the Group below and above the upper diamictite unit (D II) immediately below the Lapa Formation. The preglacial shifts are correlated with beds consisting mainly of pink dolomitized fenestral algal mats (microbialites) and bioherms of columnar stromatolites. On the other hand, the postglacial shifts above the diamictites (D II) are correlated with dolomitized carbonate rhythmites of the Lapa Formation.

The Lapa Formation, which overlies the younger diamictites (D II), is predominantly composed of rhythmically laminated argillaceous dolomites (cf. Azmy et al., 2006), with shales in the upper part (Fig. 3). Immediately above the upper Vazante Group diamictite (D II), thick organic-rich shale with dropstones (Azmy et al., 2006) deposited likely during postglacial transgression (Brody et al., 2004). The Lapa sediments represent a cap carbonate of subtidal laminated dolomitized lime mudstone alternating with clays or shales forming rhythmites (Azmy et al., 2006), which shallow upward to rhythmically bedded argillaceous dolomite and microbialaminite as well as occasional stromatolite lenses that likely deposited within the photic zone (Fig. 3).

Petrographic examination of thin sections shows that the dolomicrites are generally fabric retentive and very fine grained (Azmy et al., 2006) with no significant increase in crystal size associated with dolomitization, suggesting no extensive and/or repeated meteoric alteration.

The lack of volcanic ash layers and the absence of radiometric age estimates have made the age of the Vazante Group a matter of some debate. Previous chemostratigraphic studies of the C-isotope and ${ }^{87} \mathrm{Sr} /{ }^{86} \mathrm{Sr}$ (least radiogenic signature 0.706841 ) profiles of the Group, particularly those from the Lapa carbonates, suggested a possible correlation with similar isotopic profiles of Sturtian (800-650 Ma) sequences on the Congo Craton (Azmy et al., 2001, 2006; Misi et al., 2007). However, the recent radiometric measurements of Azmy et al. (2008) suggest an age of between 


\begin{tabular}{|c|c|c|c|c|}
\hline 윽 & $\begin{array}{l}\text { 등 } \\
\text { 윯 } \\
\text { 돈 }\end{array}$ & Member & ह5 & Lithology \\
\hline \multirow{10}{*}{$\begin{array}{l}w \\
\vdash \\
Z \\
\varangle \\
N \\
\varangle \\
>\end{array}$} & 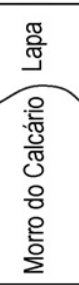 & $\begin{array}{l}\begin{array}{l}\text { Serra da Lapa Velosinho } \\
\text { Up II Re-Os } 1-1.1 \mathrm{Ga}\end{array} \\
\text { Upper Pamplona }\end{array}$ & 650 & $\begin{array}{l}\text { Dolomitic rhythmites - some } \\
\text { carbonate phylites. - basal } \\
\text { diamictites }\end{array}$ \\
\hline & \multirow{4}{*}{ 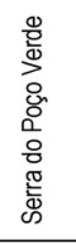 } & Middle Pamplona & 400 & $\begin{array}{l}\text { Pink dolomites - algal mats - } \\
\text { stromatolite lenses - breccia }\end{array}$ \\
\hline & & Lower Pamplona & 200 & $\begin{array}{l}\text { Dolomitic algal mats - } \\
\text { sandstone lenses }\end{array}$ \\
\hline & & Upper Morro do Pinheiro & 500 & $\begin{array}{l}\text { Dolomitic fenestral algal mats - } \\
\text { shale intercalations }\end{array}$ \\
\hline & & Lower Morro do Pinheiro & 500 & $\begin{array}{l}\text { Pink laminated dolomites - algal } \\
\text { mats - stromatolite lenses }\end{array}$ \\
\hline & 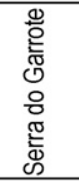 & & $>1000$ & $\begin{array}{l}\text { Dark grey to greenish slate } \\
\text { intercalated with limestones }\end{array}$ \\
\hline & \multirow{2}{*}{ 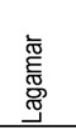 } & Sumidouro & \multirow[t]{2}{*}{250} & \multirow{2}{*}{$\begin{array}{l}\text { Alternate quartzite and } \\
\text { metasiltstones at base, overlain } \\
\text { by limestone \& pink } \\
\text { stromatolitic dolomites bioherms }\end{array}$} \\
\hline & & Arrependido & & \\
\hline & 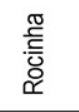 & & 1000 & $\begin{array}{l}\text { Rhythmic sandy and peletic } \\
\text { sequence with metasiltstones at } \\
\text { the base grading to } \\
\text { phospharenites at the top }\end{array}$ \\
\hline & 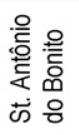 & $\leftarrow D$ & 250 & $\begin{array}{l}\text { Graded conglomeratic } \\
\text { quartzites intercalated with } \\
\text { slates - diamictites at the top. }\end{array}$ \\
\hline
\end{tabular}

Fig. 2. Schematic diagram of the Vazante Group stratigraphy showing the positions of the glacial intervals, (D) at the top of Santo Antônio do Bonito Formation and (D II) at the base of Lapa Formation (modified from Dardenne, 2001).

1.0 and $1.1 \mathrm{Ga}$ for the Vazante Group. Organic-rich shale associated with the diamictites at the base of the Lapa Formation has a Model 3 Re-Os isochron age of $1100 \pm 77 \mathrm{Ma}$ (Fig. 3). Also, Geboy (2006) obtained Re-Os ages of $1353 \pm 69$ Ma for organic-rich shales of the preglacial Serra do Garrote and glaciogenic Serra do Poço Verde Formations (middle Vazante Group, Fig. 2), respectively, that are consistent with the late Mesoproterozoic age determined by Azmy et al. (2008). In addition, Kaufman et al. (2008) documented successive isochron ages for the Serra do Garrote and Serra do Poço Verde formations between $1353 \pm 69 \mathrm{Ma}$ and $1126 \pm 47 \mathrm{Ma}$. The Vazante $\delta^{13} \mathrm{C}$ profile has negative shifts of up to $8 \%$ VPDB associated with absolute-age controlled organic-rich shale immediately above a glaciogenic interval $(1.0-1.1 \mathrm{Ga})$. Previous studies documented Mesoproterozoic $\delta^{13} \mathrm{C}$ profiles showing negative shifts of 4-6\% VPDB, but have very poor absolute age control and were not associated with glaciogenic units (e.g., Kah et al., 1999; Bartley et al., 2007).

\section{Methodology}

A summary of the methods is described below. The analytical protocol of the trace element and stable isotope measurements (carbon and oxygen) on carbonates and organic matter has been explained in detail in Azmy et al. (2001, 2006).

Samples were collected at high resolution from cores (CMM244, CMM279, CMM500, and MASW01) covering the upper Vazante
Group (Azmy et al., 2001, 2006), which were provided by the Brazilian mining company Votorantim Metais (Appendix A). Thin sections of the samples were petrographically examined under a standard polarizing microscope and cathodoluminoscope and stained with Alizarin Red-S and potassium ferricyanide solutions (Dickson, 1966). A mirror-image polished slab of each thin section was also prepared and polished for microsampling. Slabs were washed with de-ionized water and dried overnight at $50^{\circ} \mathrm{C}$ prior to the isolation of the finest grained micrites free of secondary cements. Approximately, $4 \mathrm{mg}$ were extracted under a binocular microscope from the slabs with a low-speed microdrill. The $\mathrm{C}$ - and O-analyses were run by reacting about $250 \mu \mathrm{g}$ of powder sample in inert atmosphere with concentrated (100\%) orthophosphoric acid at $70^{\circ} \mathrm{C}$ in a Thermo-Finnigan Gasbench II. The $\mathrm{CO}_{2}$ produced from the reaction was automatically delivered to a ThermoFinnigan DELTA V plus isotope ratio mass spectrometer, where the gas measured for isotope ratios. The uncertainty is better than $0.1 \%$ $(2 \sigma)$, based on repeated measurements of NBS $-19\left(\delta^{18} \mathrm{O}=-2.20 \%\right.$ 。 and $\delta^{13} \mathrm{C}=+1.95 \%$. vs. V-PDB $)$ and NBS-18 $\left(\delta^{18} \mathrm{O}=-3.00 \%\right.$ and $\delta^{13} \mathrm{C}=-5.00 \%$ vs. V-PDB) standards during each run of samples (cf. Azmy et al., 2006).

For elemental analyses, a subset of sample powder was digested in $5 \%(v / v)$ acetic acid for $70-80 \mathrm{~min}$ to eliminate leaching the detrital silicate inclusions and analysed by standard addition techniques for major (e.g., Ca, Mg), minor (e.g., Sr, Mn), and REE (Coleman et al., 1989) using a HP 4500plus ICP-MS at Memorial University of Newfoundland. The relative uncertainties of these measurements are better than 5\% (cf. Azmy et al., 2006). Normalization of Ce concentrations is based on the PAAS values (Post-Archean Australian Shale, McLennan, 1989) and the equation $\mathrm{Ce} / \mathrm{Ce}^{*}=3(\mathrm{Ce} / \mathrm{Ce}$ PAAS $) /\{(2 \mathrm{La} / \mathrm{La}$ PAAS $)+(\mathrm{Nd} / \mathrm{Nd}$ PAAS $)\} \quad$ (e.g., Shields et al., 1997).

Organic carbon isotope ratios were measured on isolated kerogen after repeated digestion with ultrapure concentrated hydrochloric acid at the isotope laboratory of Memorial University of Newfoundland, using a Carlo Erba Elemental Analyzer coupled to a 252 Finnigan Mat Mass Spectrometer. The results were normalized to the standards IAEA-CH-6 $\left(\delta^{13} \mathrm{C}=-10.43\right)$, NBS18 $\left(\delta^{13} \mathrm{C}=-5.04\right)$ and USGS24 $\left(\delta^{13} \mathrm{C}=-15.99\right)$ and the uncertainty calculated from repeated measurements was $\sim 0.2 \%$ o (cf. Azmy et al., 2006).

\section{Results and discussion}

\subsection{Sample preservation}

The degree of preservation of the Vazante carbonate samples of the current study was previously discussed in detail by Azmy et al. (2001, 2006) and carefully evaluated through a screening procedure, which involved several petrographic and geochemical techniques (e.g., Kaufman et al., 1991, 1992, 1993; Derry et al., 1992; Narbonne et al., 1994; Misi and Veizer, 1998). Thin sections were studied under a petrographic microscope to examine the grain size, recrystallization, detrital and organic contents and sedimentary structures and they were also examined under cathodoluminoscope. Only micritic material, usually exhibiting dull luminescence (cf. Rush and Chafetz, 1990), was microsampled under a binocular microscope from polished slabs, which are mirror images of the screened thin sections. The extracted powder was run for $\mathrm{C}$ - and $\mathrm{O}$-isotopes, major and minor elements and REEs. The lack of correlations of $\mathrm{Mn} / \mathrm{Sr}$ ratios with $\delta^{13} \mathrm{C}_{\mathrm{carb}}\left(R^{2}=0.008\right)$ and $\delta^{18} \mathrm{O}$ $\left(R^{2}=0.001\right)$ values (Fig. 4a,b) suggest a high degree of preservation of the $\delta^{13} \mathrm{C}$ signatures likely because the diagenetic fluids do not contain much of $\mathrm{CO}_{2}$ to reset the $\delta^{13} \mathrm{C}$ signature of carbonates. The 


\section{$200 \mathrm{~m}$}

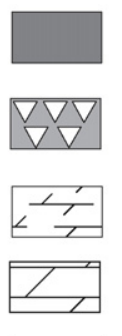

Black shale

Diamictites

Rhythmites

Laminated

argillaceous dolomite

Sandstone

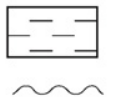

Marl

Unconformity

(D) (ID) Stromatolite

$\Longleftarrow$ Algal laminations

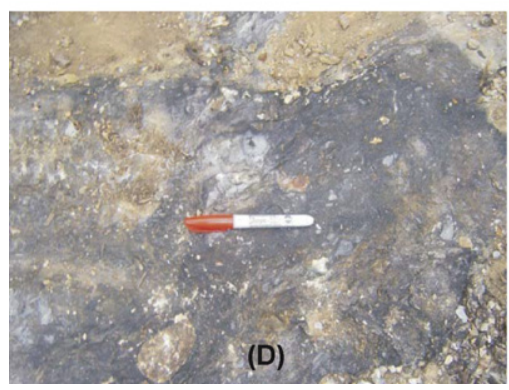

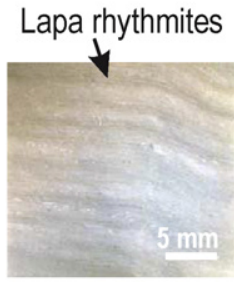

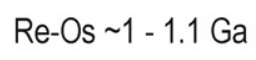

DI

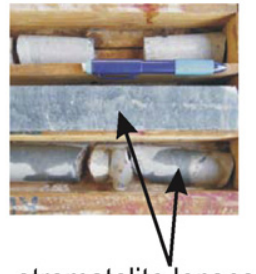

stromatolite lenses

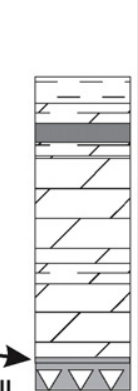

Core Formation

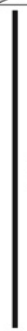

西
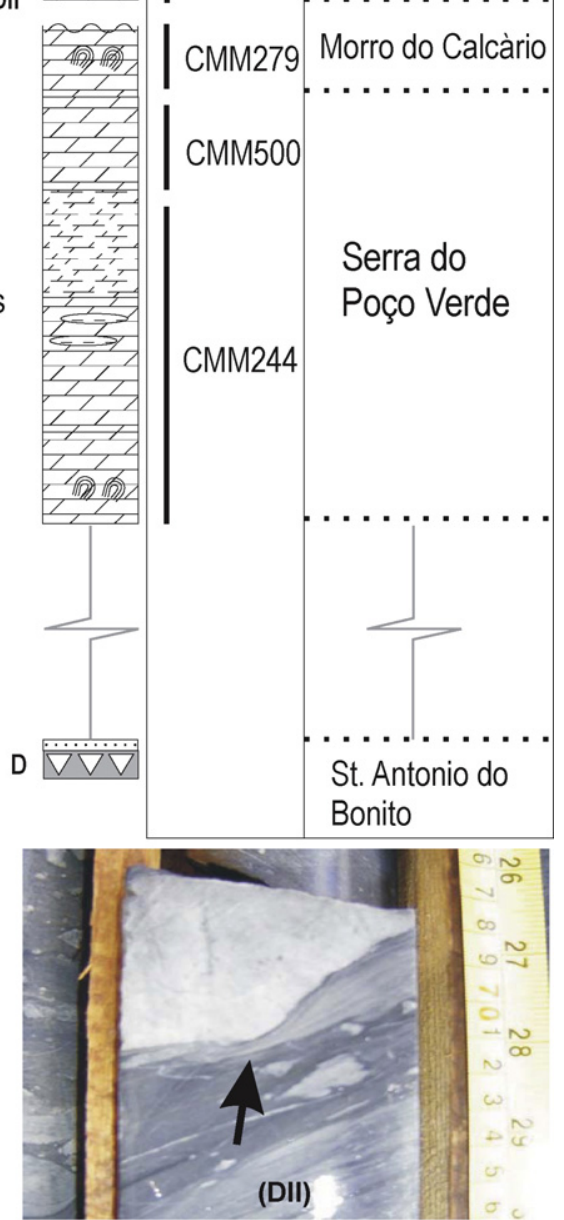

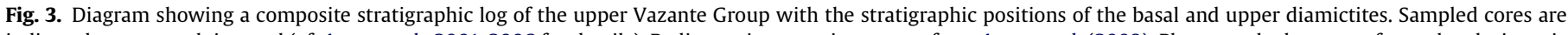

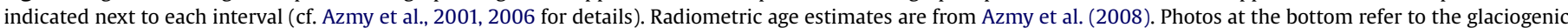

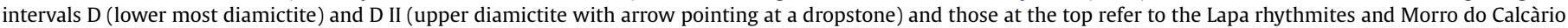
and Serra do Poço Verde stromatolite lenses, respectively.

organic matter isolated from the investigated carbonate samples has a range of $\delta^{13} C_{\text {org }}$ values between -26 and $-13 \%$. Metamorphism may result in enrichment in the $\delta^{13} \mathrm{C}_{\text {org }}$ (Schidlowski et al., 1975; Hayes et al., 1983; Holser et al., 1988; Hayes et al., 1999) but the lack of correlation between the C-isotope enrichment and organic carbon abundance (TOC) in the upper Vazante carbonates (Fig. 4c) would strongly argue against a metamorphic artifact (cf. Azmy et al., 2006). The $\delta^{13} C_{\text {org }}$ values show a parallel trend to that of $\delta^{13} C_{\text {carb }}$ (Fig. 5), which implies that the $\delta^{13} C_{\text {carb }}$ trend is likely primary, and that the variations in $\delta^{13} C_{\text {org }}$ are also primary, and it reflects changes in primary productivity in the depositional setting (cf. Azmy et al., 2006 for more details).

The $\mathrm{Th} / \mathrm{U}$ and $\mathrm{Ce} / \mathrm{Ce}^{*}$ ratios of the Vazante carbonates exhibit insignificant correlation with the detrital (siliciclastic) contents of samples (Fig. 6a,b), thus suggesting no detrital influence or overprint on the carbonate signatures. Although the influence of diagenetic alteration on the redistribution of some elements (e.g., $\mathrm{Ca}, \mathrm{Mg}, \mathrm{Na}, \mathrm{Mn}, \mathrm{Fe}, \mathrm{Sr}$, and $\mathrm{Ba}$ ) in carbonates has been established (Veizer, 1983) and used for the evaluation of carbonate preservation in both Phanerozoic (e.g., Azmy et al., 1998; Veizer et al., 1999) and Precambrian sediments (Derry et al., 1992; Kaufman and Knoll, 1995), no detailed studies have yet investigated the fractionation of REE between carbonate phases during diagenesis. Diagenetic alteration is well known to cause significant depletion of $\mathrm{Sr}$ and enrichment of $\mathrm{Mn}$ in the diagenetic carbonate phase (Veizer, 1983) and the $\mathrm{Mn} / \mathrm{Sr}$ ratio can be therefore used to evaluate the degree of carbonate preservation. The redox indicators utilized in the current study, Th/U and $\mathrm{Ce} / \mathrm{Ce}^{*}$ ratios, exhibit insignificant correlations with their $\mathrm{Mn} / \mathrm{Sr}$ counterparts (Fig. 7a,b), thus suggesting a high degree of preservation of the Vazante REE signatures particularly for Th, $\mathrm{U}$ 

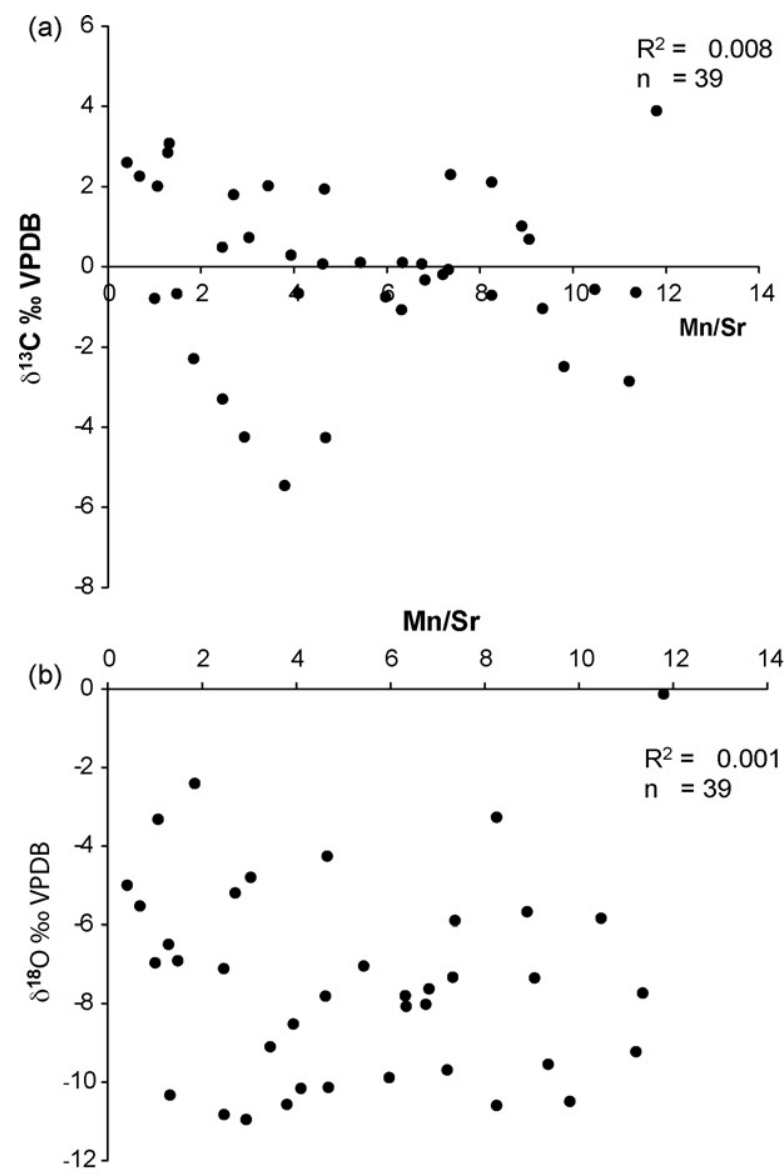

(c)

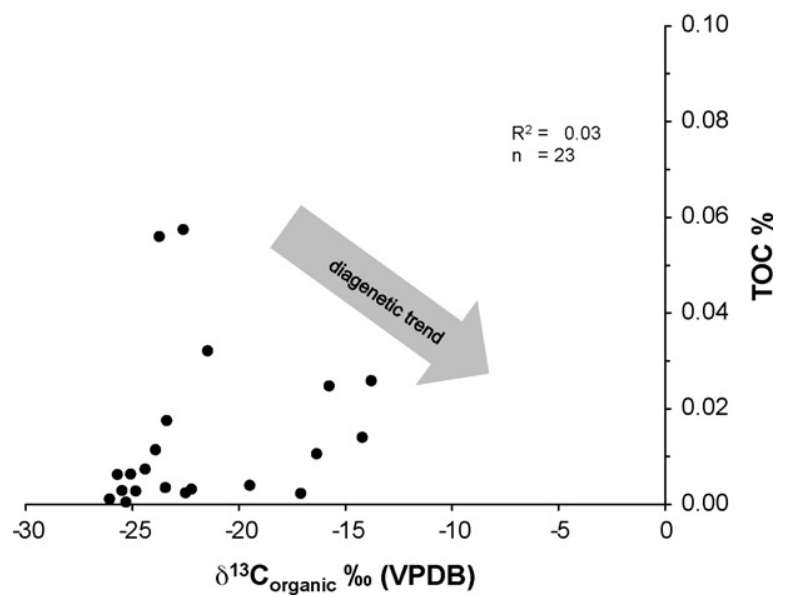

Fig. 4. Scatter diagrams of (a) Mn/Sr vs. $\delta^{13} \mathrm{C}$, (b) $\mathrm{Mn} / \mathrm{Sr}$ vs. $\delta^{18} \mathrm{O}$, and (c) $\delta^{13} \mathrm{C}$ vs. the total organic carbon contents (TOC) for dolomicrites (carbonate mud) of the upper Vazante Group showing lack of correlations.

and Ce. This is consistent with the correlation of the variations of those elements with their counterparts of the $\delta^{13} \mathrm{C}$ of the Vazante carbonate and TOC profiles (Fig. 5).

The PAAS-normalized Vazante REE patterns (McLennan, 1989) also exhibit nearly parallel profiles through the studied sequence (e.g., Bau and Alexander, 2006) although some minor deviations may be observed in the Eu values (Fig. 8) but not in the Ce which is used as a redox indicator in the current study. In most parts of the sequence, the Vazante patterns are nearly similar to those averages of the modern microbialite and Pacific Ocean water (cf. Shields and Webb, 2004 and more reference therein) but they lack the negative Ce anomaly exhibited by the Pacific Ocean water (Fig. 8).

\subsection{Redox conditions}

Anoxic conditions have been known to be responsible for extinction events of biota or dramatic reduction in organic productivity during the Phanerozoic and Proterozoic (e.g., Erwin, 1993; Hoffman et al., 1998 and more references therein). Levels of oxygen in the water column, expressed as the redox conditions, influence the oxidation state of some elements and selectively control their solubility in seawater and consequently their degree of enrichment in marine sediments (e.g., Myers and Wignall, 1987; Wignall and Twitchett, 1996; Arnaboldi and Meyers, 2007; Wignall et al., 2007). Uranium is among the elements which are sensitive to redox conditions in seawater. In oxidizing environment, uranium ions maintain the higher oxidation state $\left(\mathrm{U}^{+6}\right)$ and form uranyl carbonate, which is soluble in water whereas in reducing conditions, they retain the lower oxidation state $\left(\mathrm{U}^{+4}\right)$ and form the insoluble uranous fluoride which is trapped into marine carbonates (Wignall and Twitchett, 1996). In contrast, thorium is not affected by the redox conditions of water column and occurs permanently in the insoluble $\mathrm{Th}^{+4}$ state. Accordingly, sediments of anoxic environments are richer in uranium and have lower Th/U than those of oxic environments. Therefore, the $\mathrm{Th} / \mathrm{U}$ ratio has been used as a proxy for environmental redox conditions, with ratios $<2$ in anoxic marine sediments, $2-7$ in oxic sediments, and $>7$ in intensely oxidizing terrestrial environments (cf. Wignall and Twitchett, 1996).

The upper part of the Vazante Group has a distinct glaciogenic diamictite unit (D II) at the base of the Lapa Formation (Fig. 5), which is overlain by cap carbonates (Azmy et al., 2001, 2006; Misi et al., 2007). The $\delta^{13} \mathrm{C}$ profile of the succession has remarkable primary shifts (Fig. 5) correlated with the stratigraphic levels immediately below and above the diamictite unit (Azmy et al., 2001, 2006). Recent Re-Os and U-Pb radiogenic-age studies give ages of $\sim 1.0-1.1 \mathrm{Ga}$, suggesting that the Vazante Group was deposited during the late Mesoproterozoic (Azmy et al., 2008). Although the global $\delta^{13} \mathrm{C}$ profile for late Mesoproterozoic cap carbonates is sparse (cf. Kah et al., 1999; Lindsay and Brasier, 2002; Bartley et al., 2007), comparable Neoproterozoic C-isotope shifts have been documented in association with global glacial events (cf. Halverson et al., 2005, 2007; Fike et al., 2007; Jiang et al., 2007 and more references therein) and can be utilized to shed the light on the depositional environment of the Vazante Basin.

The exact processes that might have resulted in large $\delta^{13} \mathrm{C}$ shifts in marine sediments are still a matter of debate. The "Snowball Earth hypothesis" (e.g., Hoffman et al., 1998; Hoffman and Schrag, 2000) suggests that an extensive global glaciation during the Neoproterozoic reached at least near the paleoequatorial latitudes and isolated the ocean from atmosphere. The $\mathrm{CO}_{2}$ evolved, in later stages, from volcanoes resulted in melting ice and initiated the precipitation of cap carbonates in ${ }^{13} \mathrm{C}$-depleted oceans of low organic productivity but high alkalinity influx caused by enhanced weathering. Also, the postglacial ocean mixing and upwelling currents might have brought deep ${ }^{12} \mathrm{C}$-rich water to shallow shelf environments which resulted in the precipitation of ${ }^{13} \mathrm{C}$-depleted carbonates (e.g., Knoll et al., 1986; Kaufman et al., 1993; Grotzinger and Knoll, 1995). Alternatively, the released methane from exposed organic-rich sediments, by drop in sea level during glaciation, was trapped as methane hydrate in permafrost. The postglacial warming and sea level rise released methane in shelf water which resulted in the precipitation of ${ }^{13} \mathrm{C}$-depleted carbonates (Kennedy et al., 2001).

On the other hand, C-isotope shifts have been documented in preglacial carbonates and were also attributed to a possible release 


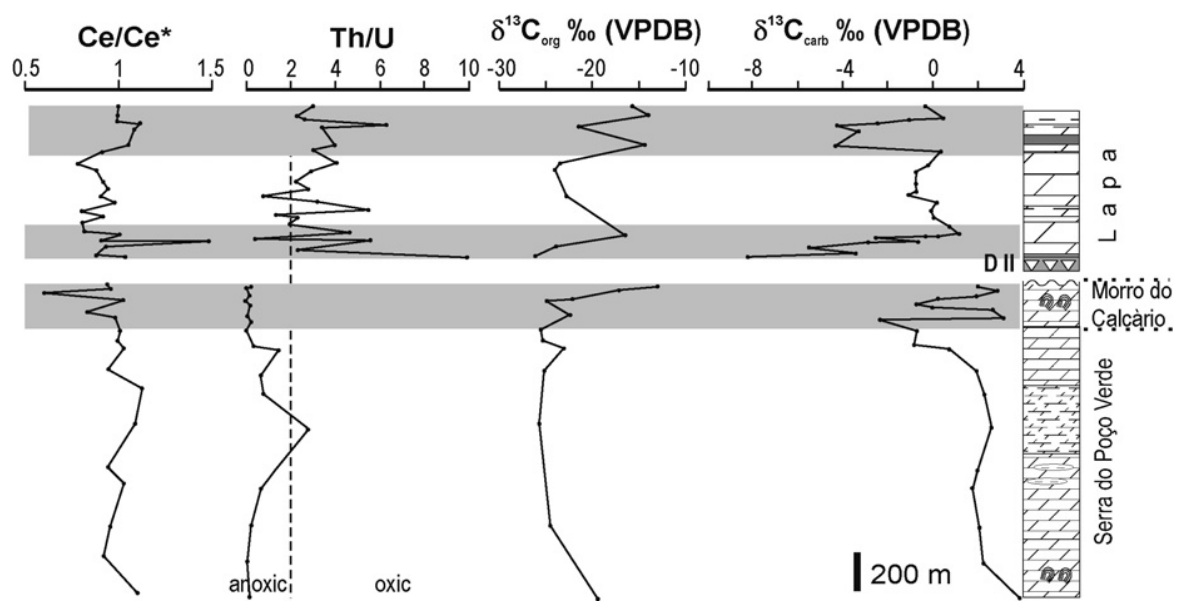

Fig. 5. Composite diagram showing the $\delta^{13} C_{\text {carb }}, \delta^{13} C_{o r g}$, Th/U and Ce/Ce ${ }^{*}$ profiles of the upper Vazante carbonates (details in text). Legend as in Fig. 3 .

of methane from organic-rich sediments on continental margins (Halverson et al., 2002; Schrag et al., 2002).

The $\delta^{13} \mathrm{C}_{\text {carb }}$ profile of the upper Vazante (Fig. 5) exhibits two major different baselines, below and above the basal Lapa diamictite (D II). The preglacial baseline occurs at 3\% and the postglacial baseline at $\sim 0 \%$ o (VPDB), respectively (Fig. 5 ). Although variations
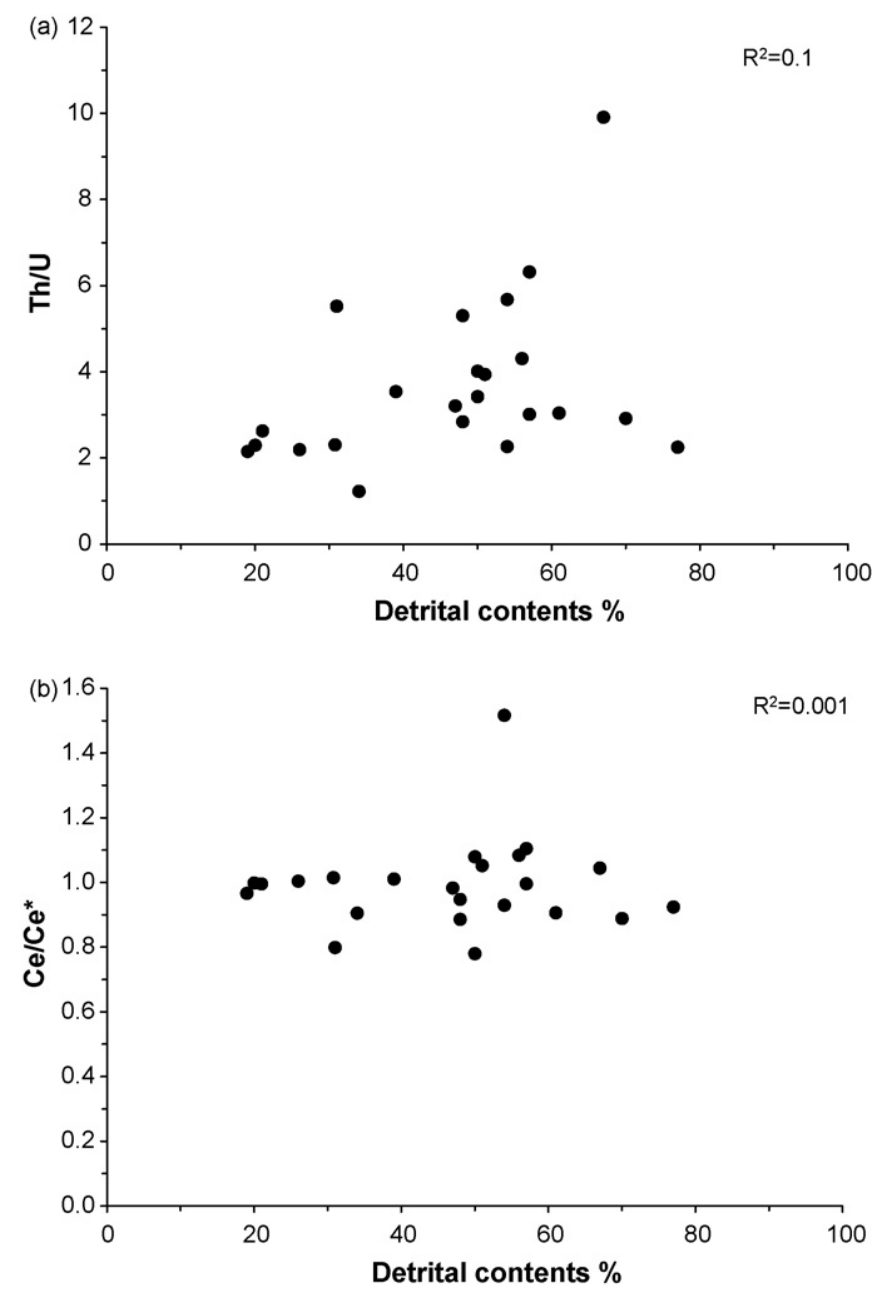

Fig. 6. Scatter diagrams of the detrital contents vs. (a) Th/U and (b) $\mathrm{Ce} / \mathrm{Ce}^{*}$ in the investigated Vazante carbonates exhibiting insignificant correlation. Detail in text. in Precambrian seawater carbon budget can be, at times, attributed to paleoceanographic patterns (e.g., Knoll et al., 1986; Kaufman et al., 1993; Grotzinger and Knoll, 1995), the sedimentological evidence suggests that the Vazante carbonates were mainly deposited in a shallow marine platform setting (Dardenne, 1978; Dardenne and Walde, 1979; Madalosso, 1979; Karfunkel and Hoppe, 1988; Fairchild et al., 1996; Azmy et al., 2001; Dardenne, 2001; Misi, 2001,
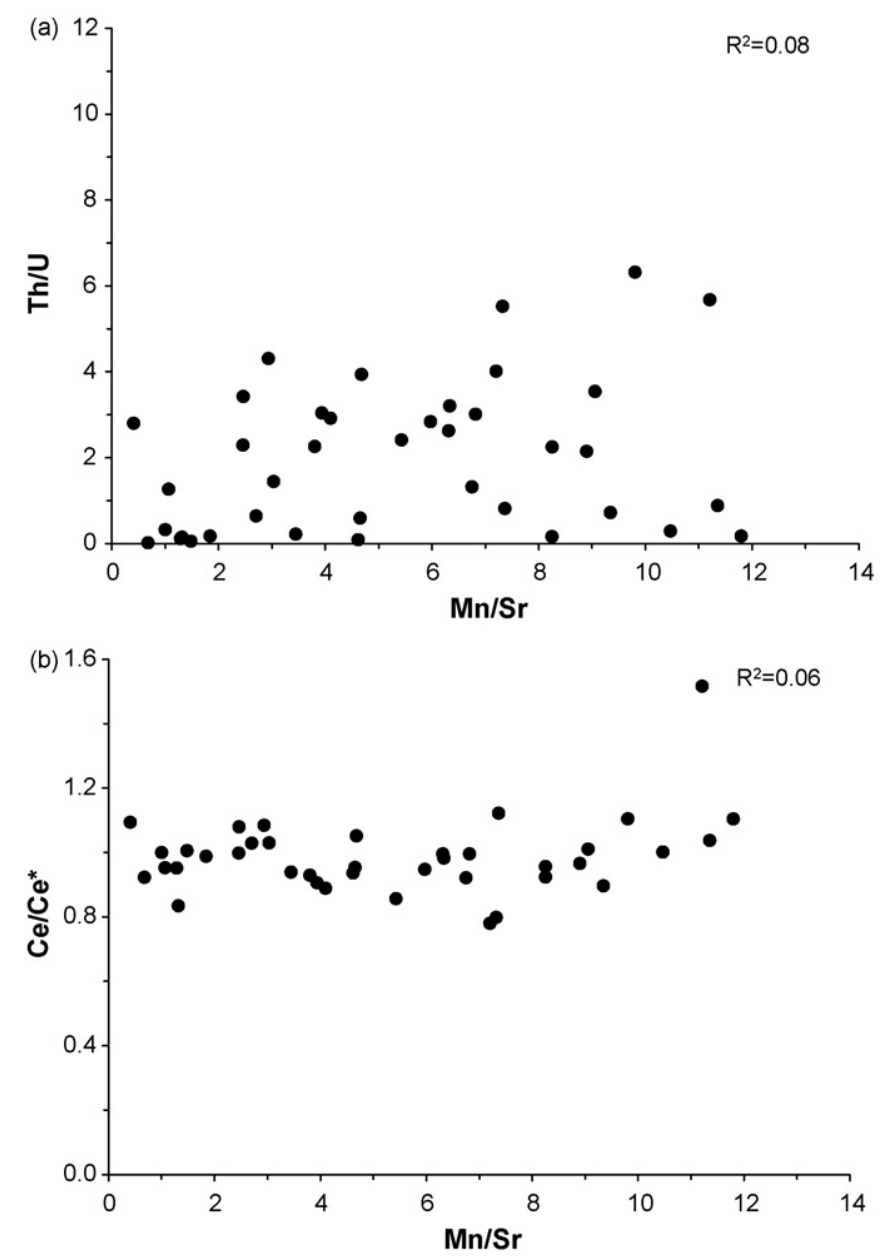

Fig. 7. Scatter diagrams of Mn/Sr vs. (a) Th/U and (b) Ce/Ce* showing insignificant correlations. See text for detail. 


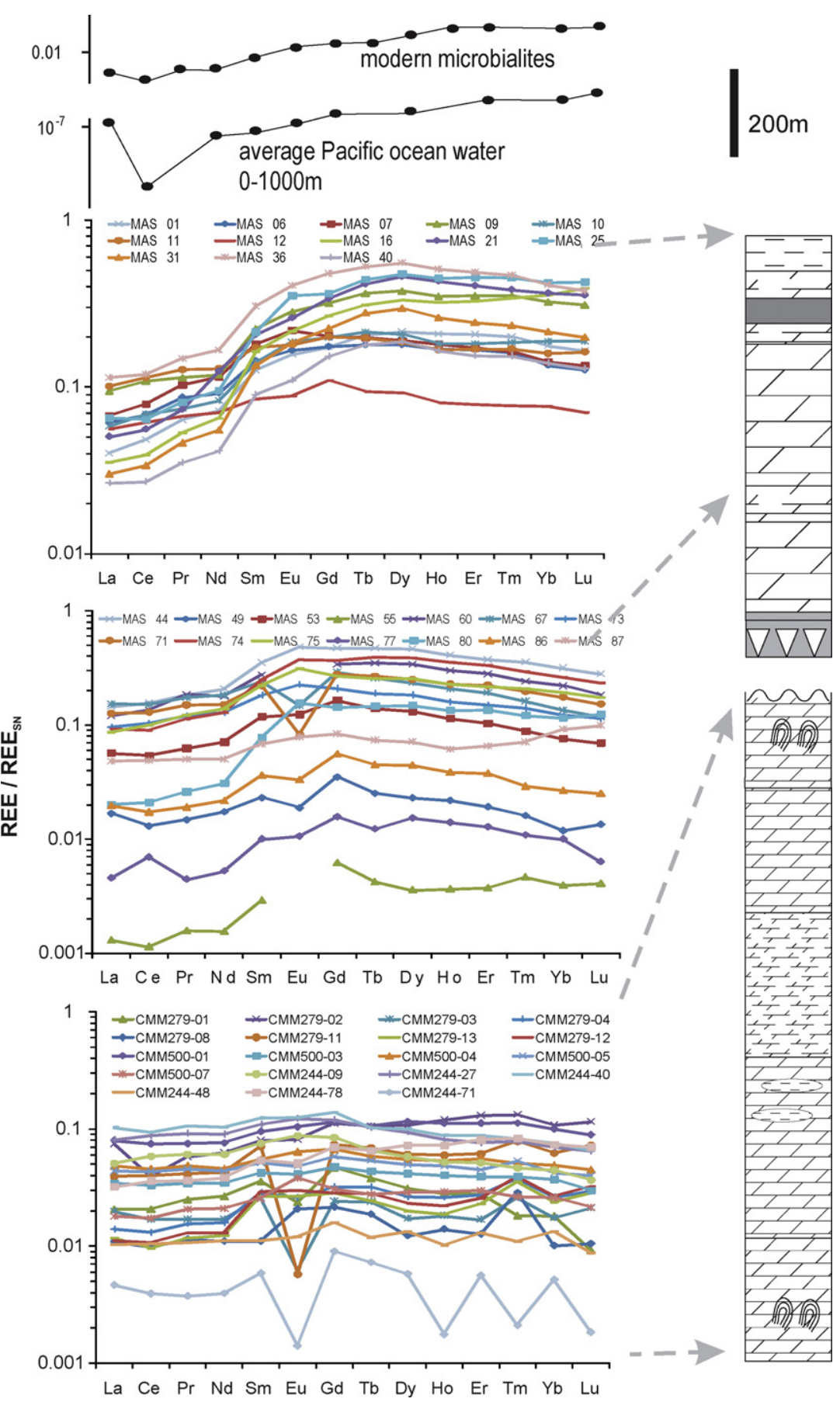

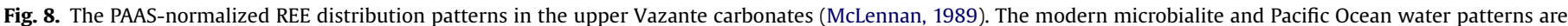

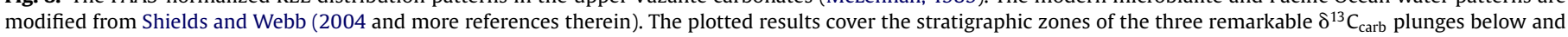
above the diamictites (D II).

Misi et al., 2007). Therefore, the general long-term decrease in the $\delta^{13} \mathrm{C}_{\text {carb }}$ of cap carbonates (Fig. 5) might reflect the impact of glaciation on the abundance and primary productivity of microbial biota in the postglacial Vazante Ocean. Excluding the $\delta^{13} \mathrm{C}_{\text {carb }}$ values of swings associated with glacial events, the global C-isotope signatures of the Neoproterozoic carbonates (cf. Halverson et al., 2005, 2007) show generally more enriched values (around 5\%。 VPDB) compared with those of the Vazante carbonates (around $0 \%$ VPDB), which may suggest that the evolution and abundance of microorganisms in late Mesoproterozoic oceans might have increased with time towards the late Neoproterozoic. However, this needs fur- ther study as relatively high $\delta^{13} C_{\text {carb }}$ values, up to $4 \%$ 。 VPDB, have been recently documented for some older carbonate muds (late Mesoproterozoic - Middle Riphean) from the Avzyan Formation of southern Urals, Russia (Bartley et al., 2007).

The upper Vazante $\delta^{13} C_{\text {carb }}$ profile shows three major primary plunges towards isotopically lighter carbon (Fig. 5), a preglacial decrease of $\sim 5 \%$ in mainly stromatolite-rich carbonates and microbial laminites (Azmy et al., 2001) immediately before the basal Lapa diamictite (D II) and two postglacial plunges of $\sim 8 \%$ o and $\sim 5 \%$ o in cap carbonate rhythmites after glaciation (Azmy et al., 2006). The lower postglacial plunge occurs immediately above the diamictite 
unit and the upper plunge is associated with a shale layer at the top of the Lapa Formation (Fig. 5).

The preglacial shift ( $\sim 5 \%$ ) correlates with Th/U values of $0.1-1.4$ (Fig. 5) and thus is associated with precipitation of carbonates in reducing (anoxic-dysoxic) conditions $(\mathrm{Th} / \mathrm{U} \leq 2)$. The association of the reducing conditions with the preglacial negative $\delta^{13} C_{\text {carb }}$ is consistent with possible release of methane from organic-rich sediments on continental margins (e.g., Halverson et al., 2002; Schrag et al., 2002). However, the lack of a supporting sedimentological evidence (e.g., Jiang et al., 2003) in the Vazante carbonates, such as tube-like structures through which gas might have escaped (e.g., Hoffman and Schrag, 2002, Wang et al., 2008), might argue against the methane release scenario. Alternatively, the input of ${ }^{12} \mathrm{C}$-enriched $\mathrm{CO}_{2}$ in shelf environment might have been enhanced by sea level drop, caused by early regression preceding full glaciations, which brought some of the oxygen-restricted lower shelf water close to deep shelf settings rich in organic matter.

Unlike the positive correlations of the $\delta^{13} C_{\text {carb }}$ and Th/U profiles documented for the Permo-Triassic (e.g., Wignall and Twitchett, 1996) and Precambrian-Cambrian (Kimura and Watanabe, 2001) boundaries, those of the postglacial upper Vazante generally exhibit an opposite relationship (Fig. 5). The lower postglacial shift ( 8\%) above the diamictite D II and the upper shift ( $\sim 5 \%$ ) above the shale layer (Fig. 5) at the top of Lapa Formation (Azmy et al., 2001, 2006) correlate with $\mathrm{Th} / \mathrm{U}$ values of 9.9-4.3, respectively, suggesting carbonate precipitation in oxidizing $(\mathrm{Th}>2)$ environments.

The lower postglacial $\delta^{13} C_{\text {carb }}$ shift, immediately above the diamictite (D II), correlates with $\mathrm{Th} / \mathrm{U}$ ratios that evolve from strongly reducing conditions $(\mathrm{Th} / \mathrm{U}=0.1)$ towards highly oxidizing conditions $(\mathrm{Th} / \mathrm{U}=9.9)$ and the signal continues upsection towards normal oxidizing conditions $(\mathrm{Th} / \mathrm{U}=2-6)$. The remarkable recovery in $\delta^{13} \mathrm{C}_{\text {carb }}$ after the plunge (Fig. 5) likely reflects the combined effect of climate warming caused by high $\mathrm{CO}_{2}$ input possibly from extensive volcanic activity, melting of ice caps, alkalinity influx and gradual increase in organic productivity. These factors would have triggered the precipitation of cap carbonates in ocean waters of low organic productivity (e.g., Kennedy et al., 2001; Halverson et al., 2002; Schrag et al., 2002). The highly oxic conditions $(\mathrm{Th} / \mathrm{U}=9.9)$, that immediately followed the termination of glaciations, might have been caused by the high solubility of oxygen in relatively cold water with initial restricted biota (cf. Olcott et al., 2005) and oxygen concentrations decreased with the progressive recovery of primary productivity after glaciation. Also, high Th/U ratios (>7) have been suggested to reflect terrestrial inputs (Wignall and Twitchett, 1996). The upper Vazante Th/U values (up to 9.9), correlated with stratigraphic levels immediately above the diamictite, are consistent with the argillaceous nature of the Lapa cap carbonates (rhythmites). This could reflect the effect of differential input of weathered continental materials due to possible fluctuations in the sea level during the initial stages of ice melting. However, the lack of correlation between the $\delta^{13} C_{\text {carb }}$ and the amount of carbonate in the samples suggests that the terrestrial input did not have enough organic matter to significantly influence the $\delta^{13} \mathrm{C}$ signatures (Azmy et al., 2006).

The uppermost postglacial negative $\delta^{13} C_{\text {carb }}$ shift $(\sim 5 \%)$ is recorded in rhythmites of laminated argillaceous carbonates (Azmy et al., 2006) overlying a shale layer and correlates with $\mathrm{Th} / \mathrm{U}$ ratios ( 2.3-6.3) of oxic conditions (Fig. 5). The upward passage of shale to carbonate rhythmites may indicate the onset of a sedimentary cycle of progressive shallowing after platform drowning, which might have resulted in a recovery in the primary productivity.

The upper Vazante $\mathrm{Ce} / \mathrm{Ce}^{*}$ profile shows a similar trend to that of $\mathrm{Th} / \mathrm{U}$ (Fig. 5). The preglacial $\delta^{13} C_{\text {carb }}$ plunge is correlated with a negative $\mathrm{Ce} / \mathrm{Ce}^{*}$ shift of $\sim 0.4$, suggesting reducing conditions (e.g., Holser et al., 1989; Shields et al., 1997), which is consistent with their low $(<2) \mathrm{Th} / \mathrm{U}$ values (Wignall and Twitchett, 1996; Wignall et al., 2007). In contrast, the lower postglacial plunge in $\delta^{13} C_{\text {carb }}$, immediately above the diamictite (D II), is correlated with a significant positive $\mathrm{Ce} / \mathrm{Ce}^{*}$ shift of $\sim 1.5$ (Fig. 5), which reflects oxidizing conditions consistent with those suggested by the high Th/U ratios ( $>2$ ). The upper postglacial drop in $\delta^{13} C_{\text {carb }}$ is correlated with only a weakly positive $\mathrm{Ce} / \mathrm{Ce}^{*}$ shift of $\sim 0.2$. This implies oxidizing conditions consistent with those reflected by $\mathrm{Th} / \mathrm{U}$ ratios at the same stratigraphic level. However, the lower Th/U and Ce/Ce* values of the upper $\delta^{13} \mathrm{C}_{\text {carb }}$ postglacial plunge, compared with their counterparts of the lower postglacial, and the lack of an immediate glaciogenic layer suggests that the uppermost $\delta^{13} C_{\text {carb }}$ was caused by a more localized oceanographic event rather than a major global climatic event. Generally speaking, the cap carbonates immediately above the diamictites (D II) show higher contents of Ce (Appendix A) compared with those of the preglacial carbonates and the uppermost carbonates above the topmost shale layer of the Lapa Formation (Fig. 3). This is consistent with the distinctive positive $\mathrm{Ce} / \mathrm{Ce}^{*}$ shift associated with those cap carbonates.

\section{Conclusions}

The $\delta^{13} \mathrm{C}$ profile of the late Mesoproterozoic upper Vazante Group carbonates, which include a glaciogenic diamictite unit, shows one preglacial and two (lower and upper) postglacial plunges towards isotopically lighter carbon. The isotopic decreases correlate with remarkable variations in the $\mathrm{Th} / \mathrm{U}$ and $\mathrm{Ce} / \mathrm{Ce}^{*}$ ratios, which reflect important redox variations in the Vazante Basin and possibly the late Mesoproterozoic ocean.

The preglacial $\delta^{13} \mathrm{C}$ plunge ( $\sim 5.4 \%$ VPDB $)$ is associated with low $\mathrm{Th} / \mathrm{U}$ ratios of $<2$ and a negative $\mathrm{Ce} / \mathrm{Ce} \mathrm{e}^{*}$ shift of $\sim 0.4$, which suggests that those carbonates were deposited in reducing conditions. The drop of sea level preceding the glaciation probably resulted in consumption of oxygen through the oxidation of organic matter in the lower shelf environment and likely higher ${ }^{12} \mathrm{C}$-input into the DIC reservoir.

In contrast, the postglacial plunges in $\delta^{13} \mathrm{C}$ correlate with high $\mathrm{Th} / \mathrm{U}$ ratios $(>2)$ and increases in $\mathrm{Ce} / \mathrm{Ce}^{*}(0.2-0.6)$, which reflect oxidizing conditions. The lower postglacial plunge ( $9 \%$ VPDB), immediately above the diamictite layer, correlates with a very high $\mathrm{Th} / \mathrm{U}$ ratio $(\sim 9.9)$ and a relatively strong increases in $\mathrm{Ce} / \mathrm{Ce}^{*}$ (0.6) suggesting significant high oxidizing conditions. Oxidation developed as a result of the high solubility of atmospheric oxygen in relative cold water following ice melting during widespread deglaciation. The upper postglacial plunge in $\delta^{13} \mathrm{C}(\sim 4.6 \%$ VPDB $)$, overlying a shale layer, correlates with a lower $\mathrm{Th} / \mathrm{U}$ ratio $(\sim 6.3)$ and a weak increase in $\mathrm{Ce} / \mathrm{Ce}^{*}(\sim 0.2)$. This suggests a local oceanographic origin rather than a major global cooling event.

The results of this study indicate that both global and local climatic and oceanic changes produced large and abrupt redox variations in the oceans during the late Mesoproterozoic.

\section{Acknowledgements}

The authors wish to thank Dr. Alcides Nobrega Sial and anonymous reviewers for their constructive reviews and Votorantim Metais (Vazante, Minas Gerais, Brazil) for providing field assistance. This project was supported by funding from Memorial University of Newfoundland, Canada (to Karem Azmy), and by the Natural Sciences and Engineering Research Council of Canada (to Paul Sylvester). 


\section{Appendix A}

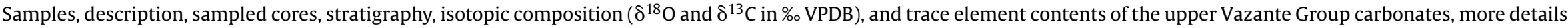
in Azmy et al. (2001, 2006).

\begin{tabular}{|c|c|c|c|c|c|c|c|c|c|c|c|c|c|c|c|c|c|c|c|c|c|c|c|c|c|c|}
\hline Sample id & Formation & Core & $\begin{array}{l}\delta^{13} \mathrm{C} \\
\% \circ \\
\text { VPDB }\end{array}$ & $\begin{array}{l}\delta^{18} \mathrm{O} \\
\% \circ \\
\text { VPDB } \\
\end{array}$ & $\begin{array}{l}\delta^{13} C_{\text {organic }} \\
\% \text { VPDB }\end{array}$ & $\begin{array}{l}\text { TOC } \\
(\%)\end{array}$ & $\begin{array}{l}\text { Detritals } \\
\text { (\%) }\end{array}$ & $\begin{array}{l}\text { Depth } \\
\text { (m) }\end{array}$ & $\begin{array}{l}\mathrm{Mn} \\
(\mathrm{ppm})\end{array}$ & $\begin{array}{l}\mathrm{Sr} \\
(\mathrm{ppm})\end{array}$ & $\begin{array}{l}\mathrm{La} \\
(\mathrm{ppb})\end{array}$ & $\begin{array}{l}\mathrm{Ce} \\
(\mathrm{ppb})\end{array}$ & $\begin{array}{l}\mathrm{Pr} \\
(\mathrm{ppb})\end{array}$ & $\begin{array}{l}\mathrm{Nd} \\
(\mathrm{ppb})\end{array}$ & $\begin{array}{l}\mathrm{Sm} \\
(\mathrm{ppb})\end{array}$ & $\begin{array}{l}\mathrm{Eu} \\
(\mathrm{ppb})\end{array}$ & $\begin{array}{l}\mathrm{Gd} \\
(\mathrm{ppb})\end{array}$ & $\begin{array}{l}\mathrm{Tb} \\
(\mathrm{ppb})\end{array}$ & $\begin{array}{l}\text { Dy } \\
(\mathrm{ppb})\end{array}$ & $\begin{array}{l}\text { Ho } \\
\text { (ppb) }\end{array}$ & $\begin{array}{l}\text { Er } \\
(\mathrm{ppb})\end{array}$ & $\begin{array}{l}\text { Tm } \\
(\mathrm{ppb})\end{array}$ & $\begin{array}{l}\mathrm{Yb} \\
(\mathrm{ppb})\end{array}$ & $\begin{array}{l}\mathrm{Lu} \\
(\mathrm{ppb})\end{array}$ & $\begin{array}{l}\text { Th } \\
(\mathrm{ppb})\end{array}$ & $\begin{array}{l}\mathrm{U} \\
(\mathrm{ppb})\end{array}$ \\
\hline MAS-01 & $\begin{array}{l}\text { Serra da Lapa } \\
\text { Velosinho }\end{array}$ & MASW01 & -0.3 & -7.6 & -15.8 & 0.02 & 57 & 54.9 & 232 & 34 & 1539 & 3856 & 562 & 2451 & 704 & 170 & 811 & 160 & 1006 & 207 & 591 & 81 & 500 & 72 & 391 & 130 \\
\hline MAS-06 & $\begin{array}{l}\text { Serra da Lapa } \\
\text { Velosinho }\end{array}$ & MASW01 & 0.5 & -7.1 & -13.8 & 0.03 & 20 & 109.8 & 255 & 104 & 2356 & 5452 & 765 & 3117 & 798 & 180 & 816 & 138 & 840 & 167 & 477 & 65 & 380 & 55 & 440 & 192 \\
\hline MAS-07 & $\begin{array}{l}\text { Serra da Lapa } \\
\text { Velosinho }\end{array}$ & MASW01 & -1.1 & -7.8 & & & 21 & 135.5 & 587 & 93 & 2570 & 6291 & 909 & 3894 & 1005 & 236 & 944 & 154 & 888 & 179 & 490 & 66 & 399 & 58 & 673 & 256 \\
\hline MAS-09 & $\begin{array}{l}\text { Serra da Lapa } \\
\text { Velosinho }\end{array}$ & MASW01 & -2.5 & -10.5 & & & 57 & 158.6 & 2039 & 208 & 3617 & 8636 & 1005 & 4013 & 1238 & 305 & 1481 & 282 & 1765 & 347 & 1005 & 143 & 911 & 135 & 986 & 156 \\
\hline MAS- 10 & $\begin{array}{l}\text { Serra da Lapa } \\
\text { Velosinho }\end{array}$ & MASW01 & -4.2 & -11.0 & -21.5 & 0.03 & 56 & 168.0 & 411 & 140 & 2221 & 5484 & 654 & 2816 & 779 & 201 & 920 & 165 & 963 & 180 & 516 & 75 & 530 & 81 & 1119 & 260 \\
\hline MAS-11 & $\begin{array}{l}\text { Serra da Lapa } \\
\text { Velosinho }\end{array}$ & MASW01 & -3.3 & -10.8 & & & 50 & 179.2 & 207 & 84 & 3877 & 9101 & 1125 & 4370 & 959 & 194 & 934 & 152 & 871 & 166 & 481 & 69 & 449 & 70 & 2070 & 604 \\
\hline MAS-12 & $\begin{array}{l}\text { Serra da Lapa } \\
\text { Velosinho }\end{array}$ & MASW01 & -4.3 & -10.1 & -14.2 & 0.01 & 51 & 265.0 & 304 & 65 & 2142 & 4886 & 592 & 2398 & 471 & 96 & 511 & 73 & 431 & 80 & 224 & 31 & 216 & 31 & 728 & 185 \\
\hline MAS-15 & $\begin{array}{l}\text { Serra da Lapa } \\
\text { Velosinho }\end{array}$ & MASW01 & 0.1 & -8.7 & & & & & & & & & & & & & & & & & & & & & & \\
\hline MAS-16 & $\begin{array}{l}\text { Serra da Lapa } \\
\text { Velosinho }\end{array}$ & MASW01 & 0.3 & -8.5 & & & 61 & 299.7 & 319 & 81 & 1351 & 3111 & 471 & 2199 & 907 & 232 & 1242 & 240 & 1548 & 317 & 934 & 138 & 1003 & 169 & 282 & 93 \\
\hline MAS-21 & $\begin{array}{l}\text { Serra da Lapa } \\
\text { Velosinho }\end{array}$ & MASW01 & -0.2 & -9.7 & -23.4 & 0.02 & 50 & 363.5 & 497 & 69 & 1922 & 4438 & 647 & 4229 & 1146 & 280 & 1578 & 321 & 2156 & 428 & 1156 & 155 & 1033 & 154 & 989 & 246 \\
\hline MAS-25 & $\begin{array}{l}\text { Serra da Lapa } \\
\text { Velosinho }\end{array}$ & MASW01 & -0.7 & -10.2 & -23.9 & 0.01 & 70 & 405.8 & 578 & 141 & 2505 & 5113 & 717 & 3239 & 1188 & 381 & 1695 & 342 & 2226 & 445 & 1295 & 184 & 1194 & 184 & 463 & 159 \\
\hline MAS-31 & $\begin{array}{l}\text { Serra da Lapa } \\
\text { Velosinho }\end{array}$ & MASW01 & -0.7 & -10.6 & & & 77 & 467.3 & 396 & 48 & 1152 & 2701 & 410 & 1869 & 746 & 198 & 1044 & 214 & 1382 & 257 & 692 & 95 & 601 & 86 & 361 & 160 \\
\hline MAS-36 & $\begin{array}{l}\text { Serra da Lapa } \\
\text { Velosinho }\end{array}$ & MASW01 & -0.8 & -9.9 & & & 48 & 505.0 & 931 & 156 & 4355 & 9481 & 1306 & 5642 & 1694 & 438 & 2226 & 408 & 2592 & 503 & 1386 & 190 & 1153 & 163 & 955 & 336 \\
\hline MAS-40 & $\begin{array}{l}\text { Serra da Lapa } \\
\text { Velosinho }\end{array}$ & MASW01 & -1.0 & -9.5 & -22.6 & 0.06 & & 539.3 & 691 & 74 & 1018 & 2157 & 312 & 1410 & 500 & 119 & 710 & 139 & 877 & 163 & 441 & 62 & 393 & 56 & 58 & 80 \\
\hline MAS-44 & $\begin{array}{l}\text { Serra da Lapa } \\
\text { Velosinho }\end{array}$ & MASW01 & 0.1 & -8.1 & & & 47 & 570.2 & 494 & 78 & 5539 & 12397 & 1622 & 7022 & 1942 & 520 & 2201 & 365 & 2177 & 407 & 1061 & 144 & 889 & 122 & 417 & 130 \\
\hline MAS-49 & $\begin{array}{l}\text { Serra da Lapa } \\
\text { Velosinho }\end{array}$ & MASW01 & -0.1 & -7.3 & & & 31 & 614.5 & 637 & 87 & 641 & 1033 & 131 & 586 & 128 & 20 & 164 & 20 & 107 & 22 & 55 & 6 & 33 & 6 & 16 & 3 \\
\hline MAS-53 & $\begin{array}{l}\text { Serra da Lapa } \\
\text { Velosinho }\end{array}$ & MASW01 & 0.1 & -8.0 & & & & 645.4 & 688 & 102 & 2167 & 4319 & 552 & 2408 & 658 & 134 & 767 & 108 & 619 & 113 & 295 & 36 & 214 & 30 & 71 & 54 \\
\hline MAS-55 & $\begin{array}{l}\text { Serra da Lapa } \\
\text { Velosinho }\end{array}$ & MASW01 & 0.1 & -7.0 & & & & 658.5 & 532 & 98 & 50 & 91 & 14 & 53 & 16 & & 29 & 3 & 17 & 4 & 11 & 2 & 11 & 2 & 9 & 4 \\
\hline MAS-60 & $\begin{array}{l}\text { Serra da Lapa } \\
\text { Velosinho }\end{array}$ & MASW01 & 0.7 & -7.3 & & & 39 & 696.0 & 498 & 55 & 4593 & 10725 & 1636 & 6033 & 1528 & & 1586 & 270 & 1594 & 296 & 798 & 98 & 621 & 79 & 537 & 152 \\
\hline MAS-67 & $\begin{array}{l}\text { Serra da Lapa } \\
\text { Velosinho }\end{array}$ & MASW01 & 1.0 & -5.7 & & & 19 & 738.2 & 383 & 43 & 5867 & 12044 & 1541 & 6216 & 1341 & 159 & 1358 & 201 & 1103 & 207 & 548 & 66 & 383 & 51 & 334 & 155 \\
\hline MAS-71 & $\begin{array}{l}\text { Serra da Lapa } \\
\text { Velosinho }\end{array}$ & MASW01 & 0.2 & -6.1 & & & 26 & 755.0 & & & 4827 & 10298 & 1321 & 5111 & 1230 & 89 & 1295 & 207 & 1173 & 226 & 635 & 80 & 494 & 66 & 289 & 132 \\
\hline MAS-73 & $\begin{array}{l}\text { Serra da Lapa } \\
\text { Velosinho }\end{array}$ & MASW01 & -0.3 & -5.8 & -16.4 & 0.01 & 31 & 760.3 & & & 3658 & 8230 & 1063 & 4333 & 1014 & 244 & 972 & 147 & 861 & 158 & 426 & 57 & 344 & 50 & 226 & 98 \\
\hline MAS-74 & $\begin{array}{l}\text { Serra da Lapa } \\
\text { Velosinho }\end{array}$ & MASW01 & -2.5 & -6.9 & & & 34 & 767.0 & & & 3503 & 7146 & 994 & 4328 & 1385 & 404 & 1733 & 306 & 1832 & 353 & 955 & 120 & 739 & 101 & 333 & 272 \\
\hline MAS-75 & $\begin{array}{l}\text { Serra da Lapa } \\
\text { Velosinho }\end{array}$ & MASW01 & -0.6 & -5.8 & & & & 777.2 & 278 & 27 & 3331 & 7963 & 1082 & 4718 & 1228 & 337 & 1257 & 198 & 1188 & 226 & 620 & 85 & 542 & 76 & 359 & 1221 \\
\hline MAS-77 & $\begin{array}{l}\text { Serra da Lapa } \\
\text { Velosinho }\end{array}$ & MASW01 & -2.9 & -9.2 & & & 54 & 792.1 & 1143 & 102 & 173 & 552 & 39 & 178 & 55 & 11 & 73 & 9 & 72 & 14 & 37 & 4 & 28 & 3 & 40 & 7 \\
\hline MAS-80 & $\begin{array}{l}\text { Serra da Lapa } \\
\text { Velosinho }\end{array}$ & MASW01 & -5.5 & -10.6 & -23.7 & 0.06 & 54 & 827.6 & 646 & 170 & 771 & 1679 & 231 & 1046 & 429 & 169 & 668 & 114 & 694 & 133 & 385 & 49 & 326 & 54 & 41 & 18 \\
\hline MAS-86 & $\begin{array}{l}\text { Serra da Lapa } \\
\text { Velosinho }\end{array}$ & MASW01 & -3.4 & -8.9 & -23.4 & 0.00 & 48 & 848.7 & & & 751 & 1376 & 169 & 737 & 201 & 36 & 261 & 35 & 208 & 38 & 108 & 12 & 75 & 11 & 40 & 7 \\
\hline MAS-87 & $\begin{array}{l}\text { Serra da Lapa } \\
\text { Velosinho }\end{array}$ & MASW01 & -8.2 & -9.4 & -26.1 & 0.00 & 67 & 865.2 & & & 1848 & 3906 & 442 & 1702 & 380 & 85 & 390 & 57 & 334 & 61 & 187 & 29 & 259 & 43 & 735 & 74 \\
\hline
\end{tabular}


Appendix A (Continued)

\begin{tabular}{|c|c|c|c|c|c|c|c|c|c|c|c|c|c|c|c|c|c|c|c|c|c|c|c|c|c|c|}
\hline Sample id & Formation & Core & $\begin{array}{l}\delta^{13} \mathrm{C} \\
\% \% \\
\text { VPDB }\end{array}$ & $\begin{array}{l}\delta^{18} \mathrm{O} \\
\% \% \\
\text { VPDB }\end{array}$ & $\begin{array}{l}\delta^{13} C_{\text {organic }} \\
\% \text { VPDB }\end{array}$ & $\begin{array}{l}\text { TOC } \\
(\%)\end{array}$ & $\begin{array}{l}\text { Detritals } \\
\text { (\%) }\end{array}$ & $\begin{array}{l}\text { Depth } \\
\text { (m) }\end{array}$ & $\begin{array}{l}\mathrm{Mn} \\
(\mathrm{ppm})\end{array}$ & $\begin{array}{l}\mathrm{Sr} \\
(\mathrm{ppm})\end{array}$ & $\begin{array}{l}\mathrm{La} \\
(\mathrm{ppb})\end{array}$ & $\begin{array}{l}\mathrm{Ce} \\
(\mathrm{ppb})\end{array}$ & $\begin{array}{l}\operatorname{Pr} \\
(\mathrm{ppb})\end{array}$ & $\begin{array}{l}\mathrm{Nd} \\
(\mathrm{ppb})\end{array}$ & $\begin{array}{l}\mathrm{Sm} \\
(\mathrm{ppb})\end{array}$ & $\begin{array}{l}\mathrm{Eu} \\
(\mathrm{ppb})\end{array}$ & $\begin{array}{l}\mathrm{Gd} \\
(\mathrm{ppb})\end{array}$ & $\begin{array}{l}\mathrm{Tb} \\
(\mathrm{ppb})\end{array}$ & $\begin{array}{l}\text { Dy } \\
\text { (ppb) }\end{array}$ & $\begin{array}{l}\mathrm{Ho} \\
(\mathrm{ppb})\end{array}$ & $\begin{array}{l}\mathrm{Er} \\
(\mathrm{ppb})\end{array}$ & $\begin{array}{l}\mathrm{Tm} \\
(\mathrm{ppb})\end{array}$ & $\begin{array}{l}\mathrm{Yb} \\
(\mathrm{ppb})\end{array}$ & $\begin{array}{l}\mathrm{Lu} \\
(\mathrm{ppb})\end{array}$ & $\begin{array}{l}\text { Th } \\
(\mathrm{ppb})\end{array}$ & $\begin{array}{l}\mathrm{U} \\
(\mathrm{ppb})\end{array}$ \\
\hline CMM279-01 & $\begin{array}{l}\text { Morro do } \\
\text { Càlcario }\end{array}$ & CMM279 & 2.9 & -6.5 & -17.1 & 0.00 & & 92.0 & 90 & 70 & 786 & 1638 & 220 & 903 & 197 & 25 & 217 & 29 & 145 & 28 & 79 & 7 & 51 & 4 & 18 & 157 \\
\hline CMM279-02 & $\begin{array}{l}\text { Morro do } \\
\text { Càlcario }\end{array}$ & CMM279 & 2.0 & -7.5 & & & & 118.0 & & & 2842 & 3091 & 508 & 2114 & 443 & 88 & 520 & 82 & 501 & 118 & 370 & 53 & 302 & 50 & 32 & 176 \\
\hline CMM279-03 & $\begin{array}{l}\text { Morro do } \\
\text { Càlcario }\end{array}$ & CMM279 & 0.3 & -4.7 & -22.2 & 0.00 & & 141.0 & & & 756 & 1346 & 149 & 575 & 143 & 7 & 113 & 19 & 81 & 18 & 48 & 10 & 49 & 9 & 58 & 370 \\
\hline CMM279-04 & $\begin{array}{l}\text { Morro do } \\
\text { Càlcario }\end{array}$ & CMM279 & 0.1 & -7.8 & & & & 165.0 & 72 & 16 & 530 & 1037 & 137 & 538 & 158 & 28 & 150 & 25 & 123 & 26 & 78 & 15 & 74 & 13 & 42 & 467 \\
\hline CMM279-05 & $\begin{array}{l}\text { Morro do } \\
\text { Càlcario }\end{array}$ & CMM279 & 1.7 & -4.1 & & & & 193.0 & 185 & 37 & & & & & & & & & & & & & & & & \\
\hline CMM279-08 & $\begin{array}{l}\text { Morro do } \\
\text { Càlcario }\end{array}$ & CMM279 & 2.0 & -9.1 & -13.0 & & & 80.0 & 141 & 41 & 415 & 783 & 101 & 373 & 61 & 22 & 101 & 15 & 57 & 14 & 36 & 12 & 28 & 5 & 24 & 109 \\
\hline CMM279-11 & $\begin{array}{l}\text { Morro do } \\
\text { Càlcario }\end{array}$ & CMM279 & -0.6 & -7.7 & -24.8 & 0.00 & & 151.0 & 372 & 33 & 1498 & 3193 & 365 & 1444 & 394 & 6 & 343 & 53 & 283 & 59 & 174 & 32 & 175 & 32 & 385 & 435 \\
\hline CMM279-12 & $\begin{array}{l}\text { Morro do } \\
\text { Càlcario }\end{array}$ & CMM279 & 2.7 & -6.9 & & & & 188.0 & & & 425 & 853 & 114 & 442 & 163 & 32 & 133 & 22 & 108 & 22 & 73 & 16 & 75 & 14 & 138 & 240 \\
\hline CMM279-13 & $\begin{array}{l}\text { Morro do } \\
\text { Càlcario }\end{array}$ & CMM279 & 3.1 & -10.3 & -22.5 & 0.00 & & 212.0 & 31 & 24 & 446 & 758 & 103 & 419 & 149 & 29 & 133 & 19 & 93 & 19 & 66 & 14 & 68 & 12 & 77 & 513 \\
\hline CMM500-01 & $\begin{array}{l}\text { Serra de Poço } \\
\text { Verde }\end{array}$ & CMM500 & -2.3 & -2.4 & & & & 32.0 & 128 & 70 & 3039 & 5921 & 662 & 2583 & 528 & 113 & 532 & 82 & 541 & 111 & 319 & 45 & 282 & 39 & 262 & 1475 \\
\hline CMM500-03 & $\begin{array}{l}\text { Serra de Poço } \\
\text { Verde }\end{array}$ & CMM500 & -0.7 & -6.9 & -25.5 & 0.00 & & 76.0 & 60 & 41 & 1304 & 2629 & 303 & 1168 & 233 & 44 & 220 & 33 & 194 & 40 & 111 & 16 & 104 & 13 & 224 & 4142 \\
\hline CMM500-04 & $\begin{array}{l}\text { Serra de Poço } \\
\text { Verde }\end{array}$ & CMM500 & -0.8 & -7.0 & -25.3 & 0.00 & & 138.0 & 38 & 38 & 1837 & 3614 & 427 & 1551 & 303 & 69 & 313 & 45 & 255 & 53 & 159 & 21 & 138 & 19 & 304 & 938 \\
\hline CMM500-05 & $\begin{array}{l}\text { Serra de Poço } \\
\text { Verde }\end{array}$ & CMM500 & 0.7 & -4.8 & -23.1 & & & 173.0 & 148 & 49 & 1672 & 3434 & 401 & 1474 & 284 & 52 & 270 & 42 & 232 & 48 & 127 & 22 & 119 & 17 & 295 & 204 \\
\hline CMM500-07 & $\begin{array}{l}\text { Serra de Poço } \\
\text { Verde }\end{array}$ & CMM500 & 1.9 & -4.3 & -25.1 & 0.01 & & 286.0 & 202 & 43 & 688 & 1382 & 182 & 712 & 142 & 41 & 143 & 21 & 134 & 29 & 85 & 11 & 73 & 9 & 108 & 181 \\
\hline CMM244-09 & $\begin{array}{l}\text { Serra de Poço } \\
\text { Verde }\end{array}$ & CMM244 & 2.3 & -5.9 & & & & 96.0 & 338 & 46 & 1941 & 4634 & 534 & 2063 & 419 & 95 & 393 & 50 & 271 & 52 & 146 & 19 & 125 & 16 & 257 & 315 \\
\hline CMM244-27 & $\begin{array}{l}\text { Serra de Poço } \\
\text { Verde }\end{array}$ & CMM244 & 2.6 & -5.0 & -25.7 & 0.01 & & 263.0 & 20 & 48 & 3085 & 6999 & 809 & 3053 & 605 & 133 & 559 & 80 & 441 & 81 & 219 & 32 & 198 & 28 & 505 & 180 \\
\hline CMM244-40 & $\begin{array}{l}\text { Serra de Poço } \\
\text { Verde }\end{array}$ & CMM244 & 2.0 & -3.3 & & & & 480.7 & 69 & 65 & 3931 & 7496 & 941 & 3504 & 692 & 135 & 647 & 79 & 469 & 88 & 251 & 33 & 215 & 29 & 311 & 245 \\
\hline CMM244-48 & $\begin{array}{l}\text { Serra de Poço } \\
\text { Verde }\end{array}$ & CMM244 & 1.8 & -5.2 & & & & 566.0 & 101 & 37 & 395 & 832 & 94 & 377 & 62 & 13 & 74 & 9 & 62 & 10 & 37 & 4 & 37 & 4 & 89 & 137 \\
\hline CMM244-61 & $\begin{array}{l}\text { Serra de Poço } \\
\text { Verde }\end{array}$ & CMM244 & 2.1 & -3.3 & -24.4 & 0.01 & & 756.0 & 392 & 48 & 982 & 1753 & 197 & 693 & 127 & 13 & 159 & 19 & 128 & 26 & 84 & 10 & 56 & 8 & 128 & 781 \\
\hline CMM244-71 & $\begin{array}{l}\text { Serra de Poço } \\
\text { Verde }\end{array}$ & CMM244 & 2.3 & -5.5 & & & & 919.0 & 19 & 28 & 177 & 311 & 33 & 134 & 32 & 2 & 42 & 6 & 27 & 2 & 16 & 1 & 15 & 1 & 10 & 520 \\
\hline CMM244-78 & $\begin{array}{l}\text { Serra de Poço } \\
\text { Verde }\end{array}$ & CMM244 & 3.9 & -0.1 & -19.5 & 0.00 & & 11000 & 823 & 70 & 1222 & 2866 & 320 & 1294 & 300 & 55 & 327 & 51 & 339 & 72 & 230 & 34 & 207 & 30 & 169 & 968 \\
\hline
\end{tabular}




\section{References}

Arnaboldi, M., Meyers, P.A., 2007. Trace element indicators of increased primary production and decreased water-column ventilation during deposition of lates Pliocene sapropels at five locations across the Mediterranean Sea. Palaeogeography, Palaeoclimatology, Palaeoecology 249, 425-443.

Arnold, G.L., Anbar, A.D., Barling, J., Lyons, T.W., 2004. Molybdenum isotope evidence for widespread anoxia in mid-Proterozoic oceans. Science 304, 87-90.

Azmy, K., Kaufman, A.J., Misi, A., Oliveira, T.F., 2006. Isotope stratigraphy of the Lapa Formation, São Francisco Basin, Brazil: implications for Late Neoproterozoic glacial events in South America. Precambrian Research 149, 231-248.

Azmy, K., Kendall, B., Creaser, R.A., Heaman, L., de Oliveira, T.F., 2008. Global correlation of the Vazante Group, São Francisco Basin, Brazil: Re-Os and U-Pb radiometric age constraints. Precambrian Research 164, 160-172.

Azmy, K., Veizer, J., Bassett, M.G., Copper, P., 1998. Oxygen and carbon isotopic composition of Silurian brachiopods: implications for coeval seawater and glaciations. Geological Society of America Bulletin 110, 1499-1512.

Azmy, K., Veizer, J., Misi, A., Oliveira, T.F., Sanches, A.L., Dardenne, M.A., 2001. Dolomitization and isotope stratigraphy of the Vazante formation, São Francisco Basin, Brazil. Precambrian Research 112, 303-329.

Bartley, J.K., Kah, L.C., McWilliams, J.L., Stagner, A.F., 2007. Carbon isotope chemostratigraphy of the Middle Riphean type section (Avzyan Formation, Southern Urals, Russia): signal recovery in a fold-and-thrust belt. Chemical Geology 237, 211-232.

Bau, M., Alexander, B., 2006. Preservation of primary REE patterns without Ce anomaly during dolomitization of Mid-Paleoproterozoic limestone and the potential re-establishment of marine anoxia immediately after the "Great Oxidation Event". South African Journal of Geology 109, 81-86.

Brocks, J.J., Love, G.D., Summons, R.E., Knoll, A.H., Logan, G.A., Bowden, S.A., 2005 Biomarker evidence for green and purple sulphur bacteria in a stratified Palaeoproterozoic sea. Nature 437, 866-870.

Brody, K.B., Kaufman, A.J., Eigenbrode, J., Cody, J., 2004. Biomarker geochemistry of a post-glacial Neoproterozoic succession in Brazil. In: Abstract, Geological Society of America Annual Meeting, Denver, CO, 7 to 10 November, 2004.

Campos-Neto, M.C., 1984. Litoestratigrafia, relações estratigráficas e evolução paleogeográfica dos grupos Canastra e Paranoá (região Vazante-Lagamar, MG). Revista Brasileira de Geociências 14, 81-91.

Coleman, M.L., Walsh, J.N., Benmore, R.A., 1989. Determination of both chemical and stable isotope composition in milligram-size carbonate samples. Sedimentary Geology 65, 233-238.

Dardenne, M.A., 1978. Sentese sobre a estratigrafiado Groupo Bambuí no Brasil Central. Trigésimo Congresso Brasileiro de Geologia 2, 597-610.

Dardenne, M.A., 2000. The Brasilia fold belt. In: Cordani, U.G., Milani, E.J., Thomaz Filho, A., Campos, D.A. (Eds.), Tectonic Evolution of South América. 31st International Geological Congress. Rio de Janeiro, pp. 231-263.

Dardenne, M.A., 2001. Lithostratigraphic sedimentary sequences of the Vazante Group. In: IGCP 450 Proterozoic Sediment-Hosted Base Metal Deposits Of Western Gondwana (Abstr.), Belo Horizonte, Brazil, pp. 48-50.

Dardenne, M.A., Walde, D.H.G., 1979. A estratigrafia dos Grupos Bambuí e Macaúbas no Brasil Central. Bol. Soc. Bras. Geol., Núcleo Minas Gerais 1, 43-53.

Derry, L.A., Kaufman, A.J., Jacobsen, S.B., 1992. Sedimentary cycles and environmental change in the Late Proterozoic: evidence from stable and radiogenic isotopes. Geochimica Cosmochimica Acta 56, 1317-1329.

Dickson, J.A.D., 1966. Carbonate identification and genesis as revealed by staining. Journal of Sedimentary Petrology 36, 491-505.

Erwin, D.H., 1993. The Great Paleozoic Crisis. Columbia University Press, New York p. 327.

Fairchild, T.R., Schopf, J.W., Shen-Miller, J., Guimarǎes, E.M., Edwards, M.D., Lagstein, A., Li, X., Pabst, M., De Melo-Filho, L.S., 1996. Recent discoveries of Proterozoi microfossils in south-central Brazil. Precambrian Research 80, 125-152.

Fike, D.A., Grotzinger, J.P., Pratt, L.M., Summons, R.E., 2007. Oxidation of the Ediacaran Ocean. Nature 444, 744-747.

Fuck, R.A., Pimentel, M.M., Silva, J.H.D., 1994. Compartimentação tectônica na porção oriental da Província Tocantins. In: $38^{\circ}$ Congresso Brasileiro de Geologia, Camboriú-Sociedade Brasileira de Geologia, vol. 1, Anais, pp. 215-216.

Geboy, N.J., 2006. Rhenium-osmium age determinations of glaciogenic shales, Vazante Formation, Brazil. Unpublished M.Sc. Thesis, University of Maryland, College Park

Grotzinger, J.P., Knoll, A.H., 1995. Anomalous carbonate precipitates: is the Precambrian the key to the Permian? Palaios 10,578-596.

Halverson, G.P., Hoffman, P.F., Schrag, D.P., Maloof, A.C., Rice, A.H.N., 2005. Toward Neoproterozoic composite carbon-isotope record. Geological Society of America Bulletin 117, 1181-1207.

Halverson, G.P., Maloof, A.C., Schrag, D.P., Dudás, F.Ö., Hurtgen, M., 2007. Stratigraphy and geochemistry of a ca 800 Ma negative carbon isotope interval in northeastern Svalbard. Chemical Geology 237, 5-27.

Halverson, G.P., Hoffman, P.F., Schrag, D.P., Kaufman, A.J., 2002. A major perturbation of the carbon cycle before the Ghaub glaciation (Neoproterozoic) in Namibia: Prelude to snowball Earth?: Geochemistry, Geophysics, Geosystems, 3, 24 p. doi:10.1029/2001GC000244.

Hayes, J.M., Kaplan, I.R., Wedeking, K.W., 1983. Precambrian organic geochemistry; preservation of the record. In: Schopf, J. (Ed.), Earth's Earliest Biosphere; its Origin and Evolution. Princeton University Press, Princeton, NJ, United States, pp. 93-134.
Hayes, J.M., Strauss, H., Kaufman, A.J., 1999. The abundance of ${ }^{13} \mathrm{C}$ in marine matter and isotopic fractionation in the global biogeochemical cycle of carbon during the past $800 \mathrm{Ma}$. Chemical Geology 161, 103-125.

Hoffman, P.F., Schrag, D.P., 2000. Snowball earth. Scientific American 282 (1), 68-75.

Hoffman, P.F., Schrag, D.P., 2002. The Snowball Earth hypothesis: testing the limits of global change. Terra Nova 14, 129-155.

Hoffman, P.F., Kaufman, A.J., Halverson, G.P., Schrag, D.P., 1998. A Neoproterozoic snowball Earth. Science 281, 1342-1346.

Holser, W.T., Schidlowski, M., Mackenzie, F.T., Maynard, J.B., 1988. Geochemical cycles of carbon and sulfur. In: Gregor, C.B., Garrels, R.M., Mackenzie, F.T., Maynard, J.B. (Eds.), Chemical Evolution of the Earth. Wiley, pp. 105-173.

Holser, W.T., Schönlaub, H.-P., Attrip Jr., M., Boeckelmann, K., Klein, P., Magaritz, M., Orth, C.J., Fenninge, A., Jenny, C., Kralik, M., Mauritsch, H., Pak, E., Schramm, J.-M., Stattegger, K., Schmoeller, R., 1989. A Unique geochemical record at the permian/Triassic Boundary. Nature 337, 39-44.

Jiang, G., Kaufman, A.J., Christie-Blick, N., Zhang, S., Wu, H., 2007. Carbon isotope variability across the Ediacaran Yangtze platform in South China: implications for a large surface-to-deep ocean $\delta^{13} \mathrm{C}$ gradient. Earth and Planetary Science Letters 261, 303-320.

Jiang, G., Kennedy, M.J., Christie-Blick, N., 2003. Stable isotopic evidence for methane seeps in Neoproterozoic postglacial cap carbonates. Nature 426, 822-826.

Kah, L.C., Sherman, A.G., Narbonne, G.M., Knoll, A.H., Kaufman, A.J., $1999 . \delta^{13}$ C stratigraphy of the Proterozoic Bylot Supergroup, Baffin Island, Canada: implications for regional lithostratigraphic correlations. Canadian Journal of Earth Sciences $36,313-332$.

Kaufman, A.J., Geboy, N., Walker, R., Miller, K., Sievers, N., Poulton, S., de Oliviera, T., Misi, A., 2008. Re-Os ages of black shale in the glaciogenic Vazante Group: evidence for Mesoproterozoic ice ages in Brazil? (Abstract). IGC meeting, Oslo, August 2008. http://abstracts.congrex.com/ scripts/JMEvent/ProgrammeLogic_Abstract_P.asp?PL=Y\&Form_Id=8\&Client_Id= 'CXST'\&Project_Id='08080845'\&Person_Id=1304439.

Karfunkel, J., Hoppe, A., 1988. Late Proterozoic glaciation in central-eastern Brazil: synthesis and model. Palaeogeography, Palaeoclimatology, Palaeoecology 65, $1-21$.

Kaufman, A.J., Hayes, J.M., Knoll, A.H., Germs, G.J.B., 1991. Isotopic compositions of carbonates and organic carbon from upper Proterozoic successions in Namibia: stratigraphic variation and the effect of diagenesis and metamorphism. Precambrian Research 49, 301-327.

Kaufman, A.J., Jacobsen, S.B., Knoll, A.H., 1993. The Vendian record of Sr- and Cisotopic variations in seawater: implications for tectonics and paleoclimate. Earth Planetary Science Letters 120, 409-430.

Kaufman, A.J., Knoll, A.H., 1995. Neoproterozic variations in the C-isotopic composition of seawater: stratigraphic and biogeochemical implications. Precambrian Research 73, 27-49.

Kaufman, A.J., Knoll, A.H., Awramik, S.M., 1992. Biostratigraphic and chemostratigraphic correlation of Neoproterozoic sedimentary successions: upper Tindir Group, northwestern Canada, as a test case. Geology 20, 181-185.

Kennedy, M.J., Christie-Blick, N., Sohl, L.E., 2001. Are Proterozoic cap carbonates and isotopic excursions a record of gas hydrate destabilization following Earth's coldest intervals? Geology 29 (5), 443-446.

Kimura, H., Watanabe, Y., 2001. Oceanic anoxia at the Precambrian-Cambrian boundary. GSA Bulletin 29 (11), 995-998.

Knoll, A.H., Hayes, J.M., Kaufman, A.J., Swett, K., Lambert, I.B., 1986. Secular variations in carbon isotope ratios from Upper Proterozoic successions of Svalbard and East Greenland. Nature 321, 832-838.

Lindsay, J.F., Brasier, M.D., 2002. Did global tectonics drive early biosphere evolution? Carbon isotope record from 2.6 to $1.9 \mathrm{Ga}$ carbonates of Western Australian basins. Precambrian Research 114, 1-34.

McLennan, S.M., 1989. Rare earth elements in sedimentary rocks: influence of provenance and sedimentary processes. In: Lipin, B.R., McKay, G.A. (Eds.), Geochemistry and Mineralogy of Rare Earth Elements, vol. 21. Mineral. Soc. Am. Rev. Miner., pp. 169-200.

Madalosso, A., 1979. Stratigraphy and sedimentation of the Bambuí Group in Paracatu region, Minas Gerais, Brazil. MSc. Thesis, University of Missouri, 127 p.

Misi, A., 2001. Estratigrafia isotópica das seqüências do Supergrupo São Francisco coberturas neoproterozócias do craton do São Francisco. Idade e correlacoes. In: C.P. Pinto, M.A. Martins-Neoto (Eds.), Bacia do São Francisco. Geologia e Recursos Naturais. SBG-Minas Gerais, pp. 67-92.

Misi, A., Kaufman, A.J., Veizer, J., Powis, K., Azmy, K., Boggiani, P.C., Gaucher, C., Teixeira, J.B.G., Sanches, A.L., Iyer, S.S., 2007. Chemostratigraphic correlation of Neoproterozoic successions in South America. Chemical Geology 237, $143-167$.

Misi, A., Veizer, J., 1998. Neoproterozoic carbonate sequences of the Una Group, Irecê Basin, Brazil: chemostratigraphy, age and correlations. Precambrian Research 89 , 87-100.

Myers, K.J., Wignall, P.B., 1987. Understanding Jurassic organic-rich mudrocks-new concepts using gamma-ray spectrometry and palaeoecology: examples from the Kimmeridge Clay of Dorset and the Jet Rock of Yorkshire. In: Legget, J.K., Zuffa, G.G. (Eds.), Marine Clastic Sedimentology. Graham and Trotman, London, pp. $172-189$.

Narbonne, G.M., Kaufman, A.J., Knoll, A.H., 1994. Integrated chemostratigraphy and biostratigraphy of the Windermere Supergroup, northern Canada: implications for Neoproterozoic correlations and early evolution of animals. GSA Bulletin 106, 1281-1292. 
Olcott, A.N., Sessions, A.L., Corsetti, F.A., Kaufman, A.J., de Oliviera, T.F., 2005. Biomarker evidence for photosynthesis during Neoproterozoic glaciation. Science 310, 471-474.

Rush, P.F., Chafetz, H.S., 1990. Fabric retentive, non-luminescent brachiopods as indicators of original $\delta^{13} \mathrm{C}$ and $\delta^{18} \mathrm{O}$ compositions: a test. Journal of Sedimentary Petrology 60, 968-981.

Schidlowski, M., Eichmann, R., Junge, C.E., 1975. Precambrian sedimentary carbonates: carbon and oxygen isotope geochemistry and implications for the terrestrial oxygen budget. Precambrian Research 2, 1-69.

Schrag, D.P., Berner, R.A., Hoffman, P.F., Halverson, G.P., 2002. On the initiation of a snowball earth. Geophysics, Geochemistry, Geosystems 3 (6), doi:101029/2001GC000219.

Schen, Y., Canfield, D.E., Knoll, A.H., 2002. Middle Proterozoic ocean chemistry: evidence from the McArthur Basin, Northern Australia. American Journal of Science 302, 81-109.

Schen, Y., Knoll, A.H., Walter, M.R., 2003. Evidence for low sulphate and anoxia in a mid-Proterozoic marine basin. Nature 423, 632-635.

Shields, G.A., Stille, P., Brasier, M.D., Atudorei, V., 1997. Ocean stratification and oxygenation of the Late Precambrian environment: a post-glacial geochemical record from a Neoproterozoic section in W. Mongolia. Terra Nova 9, 218-222.

Shields, G.A., Webb, G.E., 2004. Has the REE composition of seawater changed over geological time? Chemical Geology 204, 103-107.
Valeriano, C.M., Dardenne, M.A., Fonseca, M.A., Simões, L.S.A., Seere, H.J., 2004 A evolução tectônica da Faixa Brasília. In: Mantesso-Neto, V., Bartorelli, A. Carneiro, C.D.R., Brito Neves, B.B. (Eds.), Geologia do Continente Sul Americano: Evolução da Obra de Fernando Flávio Marques de Almeida. Editora Beca, pp. 575-593.

Veizer, J., 1983. Chemical diagenesis of carbonates: theory and application of trace element technique. In: M.A. Arthur, T.F. Anderson, I.R. Kaplan, J. Veizer L.S., Land (Eds.), Stable Isotopes in Sedimentary Geology. Society of Economic Paleontologists and Mineralogists (SEPM) Short Course Notes 10 , III-1-III-100.

Veizer, J., Ala, D., Azmy, K., Bruckschen, P., Bruhn, F., Buhl, D., Carden, G., Diener A., Ebneth, S., Godderis, Y., Jasper, T., Korte, C., Pawellek, F., Podlaha, O., Strauss, H., 1999. ${ }^{87} \mathrm{Sr} /{ }^{86} \mathrm{Sr}, \delta^{18} \mathrm{O}$ and $\delta^{13} \mathrm{C}$ evolution of Phanerozoic seawater. Chemica Geology 161, 59-88.

Wang, J., Jiang, G., Xiao, S., Li, Q., Wei, Q., 2008. Carbon isotope evidence for widespread methane seeps in the ca. 635 Ma Doushantuo cap carbonate in south China. Geology 36, 347-350.

Wignall, P.B., Twitchett, R.J., 1996. Oceanic anoxia and the end Permian mass extinction. Science 272, 1155-1158.

Wignall, P.B., Zonneveld, J.-P., Newton, R.J., Amor, K., Sephton, M.A., Hartley, S., 2007. The end Triassic mass extinction record of Williston Lake, British Columbia Palaeogeography, Palaeoclimatology, Palaeoecology 253, 385-406. 